\title{
Monitoring and Evaluating a Bioretention Filter Enhanced with Zero-Valent Iron and Biochar
}

\author{
A Thesis \\ Presented to
}

the faculty of the School of Engineering and Applied Science

University of Virginia

\author{
in partial fulfillment \\ of the requirements for the degree \\ Master of Science by \\ Ryan Matthew Mahon
}

May 2017 


\title{
APPROVAL SHEET
}

\author{
This Thesis \\ is submitted in partial fulfillment of the requirements for the degree \\ of \\ Master of Science
}

Author Signature:

This Thesis has been read and approved by the examining committee:

Advisor: Teresa Culver

Committee Member: Jon Goodall

Committee Member: James Smith

Committee Member:

Committee Member:

Committee Member:

Accepted for the School of Engineering and Applied Science:

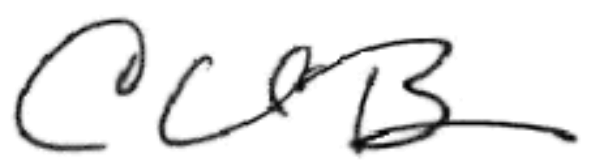

Craig $\mathrm{H}$. Benson, School of Engineering and Applied Science

May 2017 


\section{Abstract}

Stormwater has become an increasing point of concern in water pollution. Non-point source pollution caused by runoff is one of the largest polluters to waterways, such as the Chesapeake Bay. The EPA and DEQ have created Total Maximum Daily Loads (TMDLs) for the Bay watershed to protect it from high pollutant levels. To comply with state and local TMDLs, increased runoff treatment is necessary. An existing bioretention system in Charlottesville, Virginia, was enhanced with zero-valent iron and biochar in the media, as well as an internal water storage layer. Flow data along with samples taken at the inlet and outlet of the BMP were used to evaluate the performance. Five post-enhancement storms were used to determine the overall effectiveness of the BMP under natural field conditions. The enhanced bioretention system attained significant volume and peak flow reductions, ultimately stemming from the internal water storage layer. These storms saw large removal rates of total suspended solids (TSS), as well. The nutrient analysis from the post-enhancement storms did not indicate that the enhanced bioretention system was significantly removing total nitrogen and total phosphorous. However, it is believed that the reason for poor percentage nutrient reduction is the low concentrations entering the system. These concentrations are below or approach irreducible concentrations. When inlet nutrient levels were artificially increased for a storm, excellent nutrient removal rates were observed. It is believed that the media enhancements and internal water storage (IWS) layer would be more suitable at a bioretention filter with higher inlet concentrations. 


\section{Acknowledgements}

This work would not have been possible without the funding from the Mid-Atlantic Transportation Sustainabilty - University Transportation Center (MATS-UTC), as well as the Civil and Environmental Engineering Department at the University of Virginia.

- I would like to first thank my Advisor Dr. Teresa Culver for her valuable support and insight throughout the duration of this research.

- I would like to thank Tony Singh for all of his help in the lab and with equipment for the site.

- I would like to thank Andrei Ramniceanu and Keegan Gumbs for their help with site installations and construction.

- I would like to thank all the undergraduates who assisted on this project Maria Rossetti, Aaron Capelouto, and Constance Tan, as well as, the CE 4990 groups from 2015 and 2016.

- Lastly, I'd like to thank my friends and family for their support. 


\section{Table of Contents}



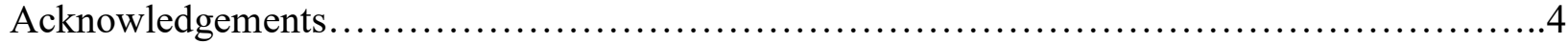

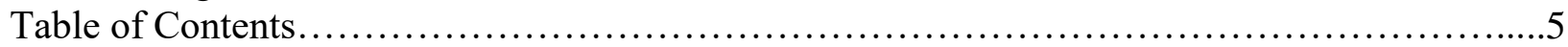

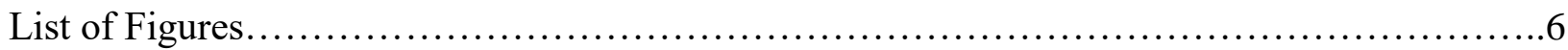



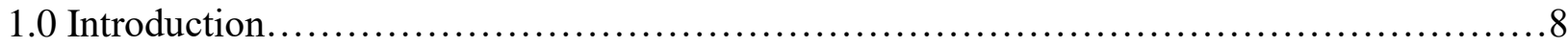

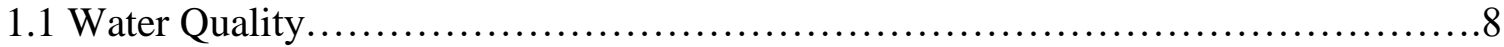

1.2 General Bioretention.......................................................... 9

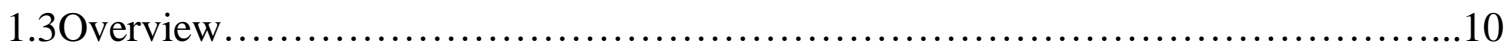

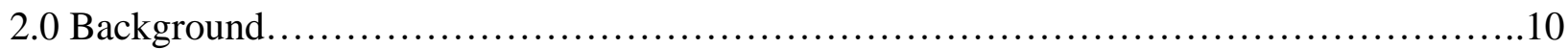

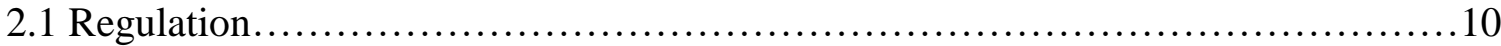



2.3 Media Enhancements........................................................ 15

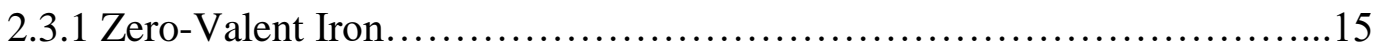

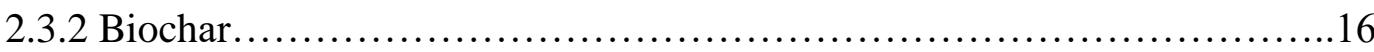

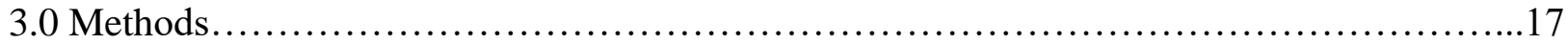

3.1 Field Site Overview........................................................ 17

3.2 Field Equipment......................................................21

3.2.1 Primary and Secondary Flow Devices..............................21

3.2.2 Sampling System ................................................ 24

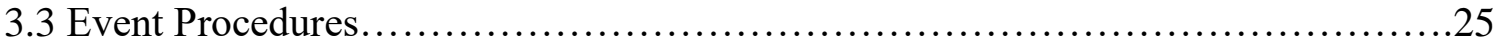

3.3.1 Standard Event Procedures..........................................25

3.3.2 Artificially Increased Influent Concentration Procedure...................25

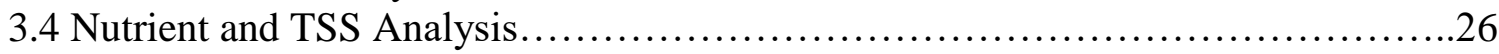

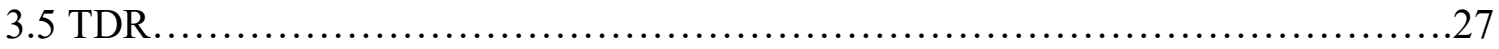

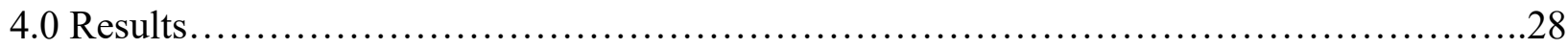

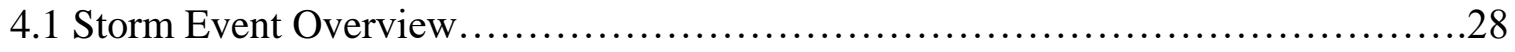

4.2 Volume Reduction............................................................

4.3 Nutrient Analysis...................................................... 34

4.4 Artificially Increased Influent Concentration ................................ 38



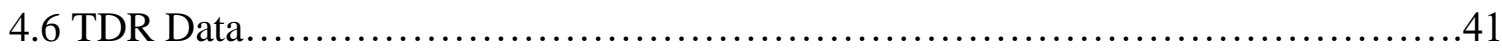



5.1 Enhanced Bioretention Strengths..........................................42

5.2 Possible Venable Bioretention Problems.......................................42

5.3 Monitoring and Analysis Challenges........................................44

5.3 .1 Equipment.................................................44

5.3.2 Rain Inconsistencies........................................... 46

5.4 Conclusion and Future Work............................................47

6.0 Appendix ............................................................... 47

Appendix A.............................................................47

Appendix B........................................................... 54






\section{List of Figures}

Figure 1. Standard bioretention filter, plan view and cross-sectional view (VA DEQ 2011)....... 2

Figure 2. Sectional view of a bioretention cell with an IWS layer (Brown et al.)....................... 2

Figure 3. Plan view of the Venable Elementary bioretention facility. Inlet channel enclosed in red, outlet area in blue. Contours indicated by elevation in feet. (modified from Ecosystem

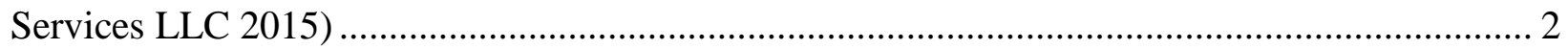

Figure 4. Venable Elementary bioretention during retro-fit construction ................................ 2

Figure 5. Section view of the Venable elementary bioretention filter....................................... 2

Figure 6. The V-notch weir (left) and 60o XL trapezoidal flume (right) in the concrete channel, picture taken from downstream facing upstream ........................................................... 2

Figure 7. the outlet 6in PVC pipe with stilling well (left) and .6 HS flume (right) .................... 2



Figure 11.The hydrograph and hyetograph from $6 / 17 / 16$ storm.......................................... 2

Figure 10. The hydrograph and hyetograph for the 4/7/16 storm........................................... 2

Figure 9. Hydrograph and hyetograph for the $11 / 9 / 15$ storm ............................................. 2

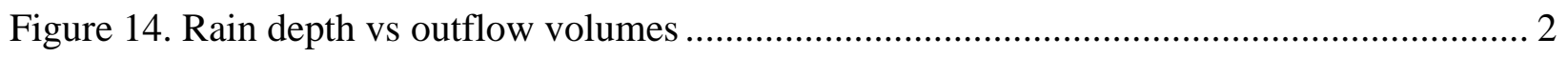

Figure 13. Rain Depth vs Inflow Volume.................................................................... 2

Figure 12. The hydrograph and hyetograph for the 4/7/16 storm ........................................ 2

Figure 15. Percent reduction of the volume and peak flow for 5 natural storms....................... 2

Figure 16. a) EMC reductions and b) load reductions on bottom at the Venable enhanced bioretention facility, level 1 and level 2 bioretention functions shown in orange and yellow,



Figure 17. Nutrient load and EMC removals for $3 / 31 / 17$ storm............................................. 2

Figure 18. percent saturation of the ZVI/Biochar/Luck Media layer using TDR data ................. 2

Figure Appendix A.1 Calibration curve for the Total Nitrogen Persulfate Digestion Method....44

Figure Appendix A.2 Calibration curve for Nitrate TNT 835 test........................46

Figure Appendix A.3 Calibration curve for Total Phosphorous TNT 843 test...................47

Figure Appendix A.4 Calibration curve for Phosphate TNT 843 test........................48 


\section{List of Tables}

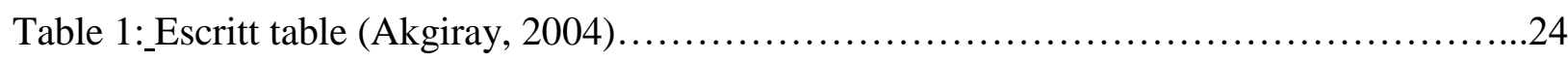

Table 2: Overview of Rain Events..............................................27

Table 3: Virginia DEQ bioretention reduction standards (Virginia BMP clearinghouse).........35

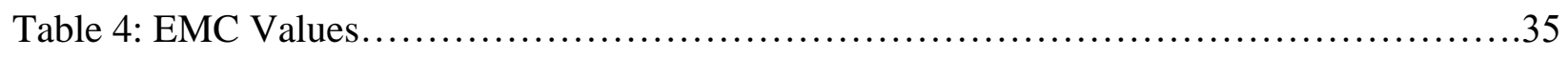

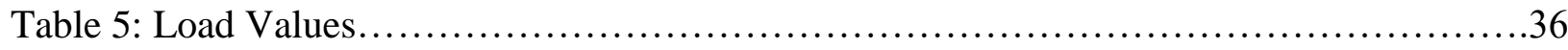

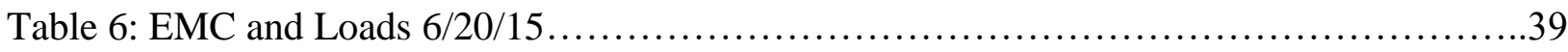

Table 7: EMC values for 4/15/15 and 6/27/15.....................................40

Table 8: Influent EMCs (Collected EMCs, Irreducible EMCs, VRRM EMCs)................44

Table 9: 2016 Rainfall depths (weather underground) and 30 year Average (NOAA, 2011).....46 


\subsection{Introduction}

\subsection{Water Quality}

As development and its associated effects on stormwater have increased, the need for infrastructure that alleviates these effects has grown. Roadways and other paved areas cause greater runoff and lack of infiltration to the soil. Human activities create large amounts of nonpoint source pollutants, especially nitrogen, phosphorous and sediments, that flow into sewer systems and nearby waterways.

Impaired waters are waterways that will not meet water quality standards set by the Clean Water Act (CWA) 1972 (EPA 2017). To manage water quality on the watershed-scale the Environmental Protection Agency (EPA) created the Total Maximum Daily Load (TMDL) program. TMDLs require the reduction of pollutants to bring a contaminated waterway back into compliance with water quality standards. According to a study done by the EPA from 2008$2009,46 \%$ of rivers and streams in the United States had high levels of phosphorous and $41 \%$ of rivers and streams had high levels of nitrogen (EPA 2016). A summary of all states reported water data stated that of 56,416 square miles of assessed bay and estuarial waters, 47,090 square miles are considered impaired; that is $83 \%$ of assessed water covered areas. Nutrients and sediments are two of the leading causes for impairment (EPA 2016).

The Virginia Department of Environmental Quality (DEQ) reported in 2014 that $75 \%$ of estuaries and $81 \%$ of lakes were considered impaired. $16 \%$ of rivers were considered impaired; however, 78\% of rivers were not assessed (Virginia DEQ). Over 50\% of Virginia's waters flow to the Chesapeake Bay, and about $56 \%$ of Virginia's land mass falls within the Chesapeake Bay watershed (USDA as of April 06, 2017), which is impaired for phosphorous, nitrogen and sediments (EPA, Sept. 29, 2016). The Chesapeake Bay TMDL program is made up of 92 
smaller TMDL programs, 39 of which are in Virginia alone (Senate of Virginia 2014). The state has a large task of reaching the TMDLs for nitrogen, phosphorous and sediments.

\subsection{General Bioretention}

The largest source of pollution to the Chesapeake bay is agricultural runoff causing $40 \%$ of Nitrogen and 50\% phosphorous in the Bay (Chesapeake Bay Foundation 2017). Stormwater runoff is the only growing source of nitrogen pollution to the bay (Chesapeake Bay Foundation 2017). Stringent TMDL regulations and growing nitrogen problems require a best management practice (BMP) that effectively reduce nutrient loads. Bioretention is a BMP being increasingly used near streets and parking lots to decrease stormwater runoff volume and reduce pollutant load. There are a number of benefits to using bioretention. Bioretention removes heavy metals and oil and grease, as well as reducing runoff volume and time to peak. These systems achieve good total suspended solid (TSS) removal due to filtration, which leads to particulate total phosphorous removal (Simpson \& Weammert, 2009). One of the issues with bioretention is nitrogen removal. Total nitrogen and nitrate removal is very low; nutrient removal is not typically the main goal when using bioretention (Washington Stormwater Center; Low Impact Development Center, 2007).If nutrient reduction could be increased in this BMP, then this method would be instrumental in reaching TMDL goals, as well as stormwater remediation.

It is hypothesized that zero-valent iron (ZVI) and biochar working together will enhance load reduction of both phosphorous and nitrogen in stormwater. Zero-valent iron and biochar are inexpensive waste products. The use of ZVI and biochar together in a bioretention filter is an idea that has not been widely researched. A laboratory study done at the University of Delaware found that the use of wood-based biochar increased nitrate removal, and the addition of ZVI resulted in increased phosphate removal (Chiu \& Imhoff, 2016). Increased removal by ZVI and 
biochar could allow for a decrease in land costs for BMPs. An existing bioretention site at Venable Elementary in Charlottesville, Virginia was enhanced with ZVI and biochar to evaluate whether phosphorous and nitrate could simultaneously be removed from stormwater in the field at the same levels seen in laboratory tests.

\subsection{Overview}

Chapter 2 summarizes the standard design of a bioretention system and reviews previous studies of iron and biochar for pollutant removal. The case study site and the enhanced bioretention system are described in chapter 3 . The experimental methods, including field and laboratory methods, are also described in chapter 3 . Chapter 4 presents the results of this study and discusses how these results compare to a standard system. Finally, chapter 5 discusses the results and possible limitations within the study. Future work and possible improvements will also be discussed and chapter 5 .

\subsection{Background}

\subsection{Regulation}

Increasing water quality issues have created a demand for clean water processes. Since the Clean Water Act was established in 1972, control of point source pollutant loads has increased. The Environmental Protection Agency was created to regulate industries directly polluting the local waterways. Today industries are required to comply with local and federal regulations and apply for national pollutant discharge elimination system (NPDES) permits. However, the NPDES permits don't consider non-point source loads in pollutant sums. Nonpoint source pollution, which originate from a number of different sources, are carried to local waterways by runoff. These diffuse sources and transport processes make non-point source pollution more challenging to measure and regulate. The EPA has created total maximum daily 
load (TMDL) plans to manage watersheds comprehensively, including non-point source pollution. A TMDL is a calculated maximum amount of a pollutant allowed into a waterbody, so that waterbody will still reach water quality standards. A TMDL is created for each pollutant that is causing impairment or threatening a waterway (EPA, 2017). TMDL programs have required local, state and federal governments to find ways of reducing water pollution. This is an especially difficult task for the expansive, multi-jurisdictional Chesapeake Bay watershed.

The Chesapeake Bay is the largest estuary in North America. The Chesapeake Bay watershed covers 64,000 square miles, 6 states and hundreds of streams and is home to hundreds of species. Most of the Chesapeake Bay and its tidal waters are listed as impaired due to excess nitrogen, phosphorous and sediment (EPA 2014). Excessive nutrient loads cause harmful algal blooms that will consume oxygen and kill off pelagic life forms and block sunlight from penetrating to benthic areas, inevitably destroying the ecosystem. In order to restore the Chesapeake Bay tidal waters the EPA created one the largest TMDLs. The Bay watershed TMDL specifies a limit of 185.9 million pounds of nitrogen, 12.5 million pounds of phosphorous and 6.45 billion pounds of sediment per year; this is equal to a 25 percent reduction of nitrogen, 24 percent reduction of phosphorous and 20 percent reduction of sediments (EPA, 2016). This TMDL design calls for practices that meet $60 \%$ of overall nitrogen, phosphorous and sediment reductions to be in place by 2017 (EPA 2016). The Bay watershed has a large system of tributaries extending through all 6 states.

The Clean Water Act in Section 303 requires states to establish water quality standards and identify the uses of these waters (Copeland, 2012). In Virginia, the Department of Environmental Quality (DEQ) creates a 303d list, which specifies sections of waterways that are 
impaired with respect to quality standards. In Virginia 10,458 miles of rivers and streams, $47 \%$ of assessed rivers and streams, are considered impaired (VA DEQ 2014).

A number of plans have been implemented to reduce nutrient and sediment loads to these impaired waterways. NPDES permits are used to reduce point source loads, which are direct, identifiable pollutant inputs into streams. The largest group of NPDES permit holders are wastewater treatment plants, but other industries have permits for discharge (EPA 2017). NPDES permits regulate point source loads but not non-point source loads. Non-point source loads include urban, agricultural and forest runoff. Urban areas experience high quantities of stormwater runoff with high pollutants coming from car oil, animal feces and miscellaneous human inputs. To manage these loads, Best Management Practices (BMPs) are being utilized. BMPs have been around for decades to help maintain water quality and conserve soil in construction areas or heavy runoff.

\subsection{Bioretention}

The main objective of a BMP is to minimize runoff volume from impervious surfaces and reduce all pollutant loads that have the potential to run into the local hydrology (Virginia Stormwater BMP Clearinghouse). There are number of different BMP types each with different strengths and weaknesses. The Virginia DEQ has stormwater BMP specifications for implementing a best management practice. Bioretention cells, sometimes called rain gardens, are a common practice. Bioretention cells can vary in size but are meant for small drainage areas. Bioretention should only be used with drainage areas of 2 acres or less (VA DEQ 2011). A bioretention cell, usually referred to as a filter when there is an underdrain, is a pit that is backfilled with engineered soil and topped with mulch and vegetation. Figure 1 shows a typical bioretention filter design from the Virginia DEQ Stormwater Design Specification. During a 
storm the water ponds 6 to 12 inches and is then treated by the soil via biological and biochemical interactions (Simpson \& Weammert 2009). Once treated, runoff water can be discharged into the local waterway or infiltrated into the ground.

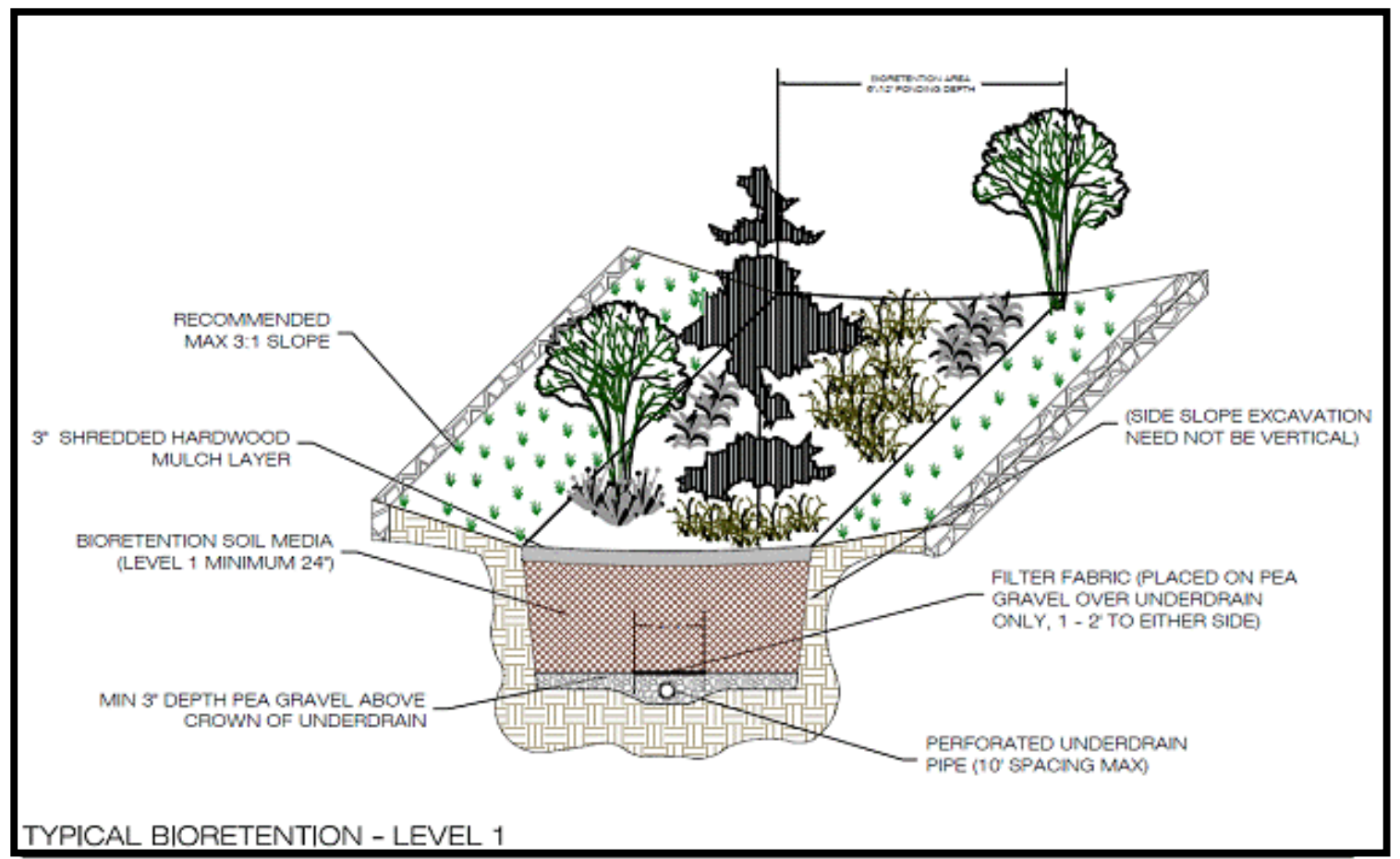

Figure 1. Standard bioretention filter, plan view and cross-sectional view (Virginia BMP Clearinghouse 2011).

Hydrologically volume and peak flow reduction are key characteristics when evaluating a BMP. In urban environments, stormwater runoff is increased due to increased impervious surfaces, which greatly increases the chances of flooding and associated damage (USGS 2016). Erosion is caused by large runoff volumes and high velocities. The Virginia Stormwater Management Handbook uses an approximate Energy Balance equation, which takes into account volumes and peak flows, to prevent erosion (VA Stormwater Management Handbook 2013).

$$
Q_{\text {Developed }} \leq I . F . x\left(Q_{\text {Pre-Developed }} x R V_{\text {Pre-Developed }}\right) / R V_{\text {Developed }}
$$

Equation 1 is the energy balance equation where: $Q_{\text {Developed }}$ is the allowable peak flow rate of runoff from the developed site, I.F. is Improvement factor, equal to 0.8 for sites $>1$ acre or 0.9 for sites $\leq 1$ acre, $Q_{\text {Pre-Developed }}$ is the peak flow rate of runoff from the site in the pre-developed 
condition, $R V_{\text {Pre-Developed }}$ is the volume of runoff from the site in the pre-developed condition and $R V_{\text {Developed }}$ is the volume of runoff from the site in the developed site. Bioretention is found to be an effective approach for reducing peak flow rates and volumes during frequent storm events (International Stormwater BMP Database 2012).

The addition of an Internal Water Storage (IWS) layer is a method that can further increase volume reduction in a bioretention cell. The IWS layer is created by adding an upturned pipe to the underdrain. This requires increased head from the infiltrating water before outflow. The IWS allows for more exfiltration. Figure 2 shows a bioretention with an IWS layer added. The IWS layer requires an increase in head before outflow, which allows the system to stay saturated longer. This in turn provides more time for exfiltration into the surrounding soils, and thus should reduce outflow volumes. The IWS may also enhance nitrogen removal by creating anoxic zones where denitrification may occur (Brown et al. 2009).

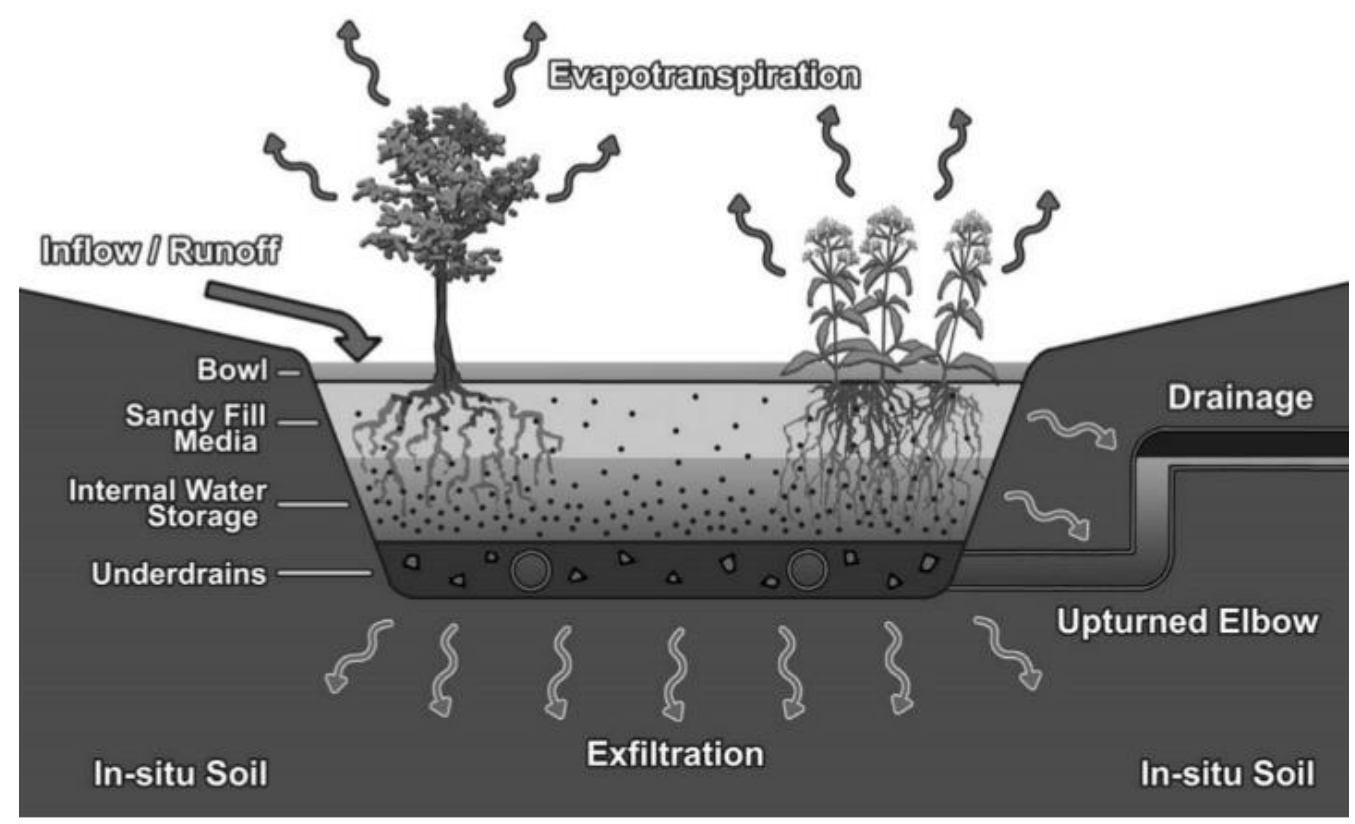

Figure 2. Sectional view of a bioretention cell with an IWS layer (Brown et al.) 
Nutrient and sediment load reductions are key characteristics when evaluating a BMP. The reduction of total mass of pollutants from inlet to outlet determines the effectiveness of the BMP. The event mean concentration reduction is also considered. This determines changes in the concentrations going into and out of the system. Equation 2 is used to calculate EMCs (Maniquiz et al. 2010).

$$
E M C=\frac{\text { Total pollutant loading per event }}{\text { total runoff volume per event }}=\frac{\sum_{i}^{n} V_{i} C_{i}}{V}
$$

where $\mathrm{V}_{\mathrm{i}}$ is the representative volume of the total storm allocated to sample, and $\mathrm{C}_{\mathrm{i}}$ is the representative concentration for $\mathrm{V}_{\mathrm{i}}$. Although EMCs are evaluated, the load reductions are the important evaluation for complying with TMDLs. The load is calculated in the numerator of equation 2.

Bioretention filters have become a more common practice. Bioretention filters achieve high sediment removal rates. Effectiveness estimates for BMPs in the Chesapeake Bay watershed shows TSS load removal rates ranging from 55\% to 90\% (Simpson and Weammert 2009). However, nutrient removal rates are lower. VA DEQ (2011) credits level 1 standard bioretention system with 55\% total phosphorous reduction and 64\% total nitrogen reduction. One alternative to increase nutrient removal rates to help achieve the requisite nutrient reductions of the Chesapeake Bay TMDLs is by modifying the BMP media.

\subsection{Media Enhancements}

\subsubsection{Zero-Valent Iron}

This work will test the efficacy of using zero-valent iron (ZVI) and biochar as media enhancements. Zero-valent iron (ZVI) has been used for decades in both wastewater and 
groundwater remediation. ZVI is an abundant reactive metal with a good redox potential. ZVI transfers electrons to contaminants which creates less toxic species. It has been used in the removal of a number of different contaminants including heavy metals, nitrates and dyes (Fu et al. 2014). Several studies have found that the nitrate removal mechanism is a direct electron transfer from ZVI; they found removal rates in batch experiments to range from $52 \%$ to $71 \%$ (Suzuki et al. 2012). A study of microbial reduction of nitrate found there was greater than $80 \%$ removal when ZVI was added to the soil. For nitrate, ZVI helped by becoming an electron donor, which occurs during anaerobic iron corrosion (Shin et al. 2008). ZVI has also been used to remove phosphates. Transition metal oxides are frequently used in phosphate remediation due to their catalytic and semi-conductive properties (Muralidhara 2014). When ZVI oxidizes and becomes iron oxide, it has beneficial adsorption properties for phosphates(Tribe 2004; Parfitt 1975). A column study found the addition of iron filings to soil returned $70-100 \%$ removal of phosphates (Erickson, Gulliver and Weiss 2011). After iron filings were used in the media of a roadside swale, Natarajan and Gulliver (2015) observed 78\% phosphate removal at a field site using synthetic stormwater runoff.

\subsubsection{Biochar}

Biochar is a growing resource worldwide with many groups advocating for its effectiveness (PPRC 2014). Biochar is very similar to activated carbon, which is another common practice in water filtration. Biochar is created when biomass, such as wood, goes through pyrolysis, the chemical change when a substance is heated. It is a large carbon source. Biochar, a natural waste product, has a high surface area and cation exchange capacity; this allows for increased sorption of contaminants. Biochar has been found to adsorb many materials from metals, phenols and organic materials (Ahmad et al. 2014). A soil study on nitrate, 
ammonium and phosphate leaching found that biochar without soil did not remove nitrate or phosphate well but had good ammonium removal rates. When the biochar was added to soil, it was found to effectively reduce nitrate and ammonium leaching (Yao et al. 2012). Biochar has been found to increase microbial activity and population which changes the biogeochemistry in the soil (Ahmad et al. 2014). The addition of biochar enhances the growth of organisms present in nitrogen cycling allowing for less leaching of nitrate (Anderson et al., 2011). Biochar increases the moisture retention in soils. It is a porous media with a high inner surface allowing for more water retention (Uzoma 2011).. It is hypothesized that biochar and ZVI together will increase nutrient removal in stormwater.

\subsection{Methods}

\subsection{Field Site Overview}

The field site for the enhanced bioretention cell was at Venable Elementary in Charlottesville, Virginia. This site was chosen in conjunction with the City of Charlottesville. There was an existing rain garden adjacent to the school parking lot with a small runoff area of .49 acres $\left(1983 \mathrm{~m}^{2}\right)$. Figure 3 displays the plan view of the bioretention cell. There is a single 
concrete inlet channel, which is $8 \mathrm{ft}(2.43 \mathrm{~m})$ long, $2 \mathrm{ft}(.61 \mathrm{~m})$ wide and $.75 \mathrm{ft}(.23 \mathrm{~m})$ deep, and a $.5 \mathrm{ft}(12.5 \mathrm{~mm})$ diameter PVC pipe serves as the single outlet pipe from the under drain.

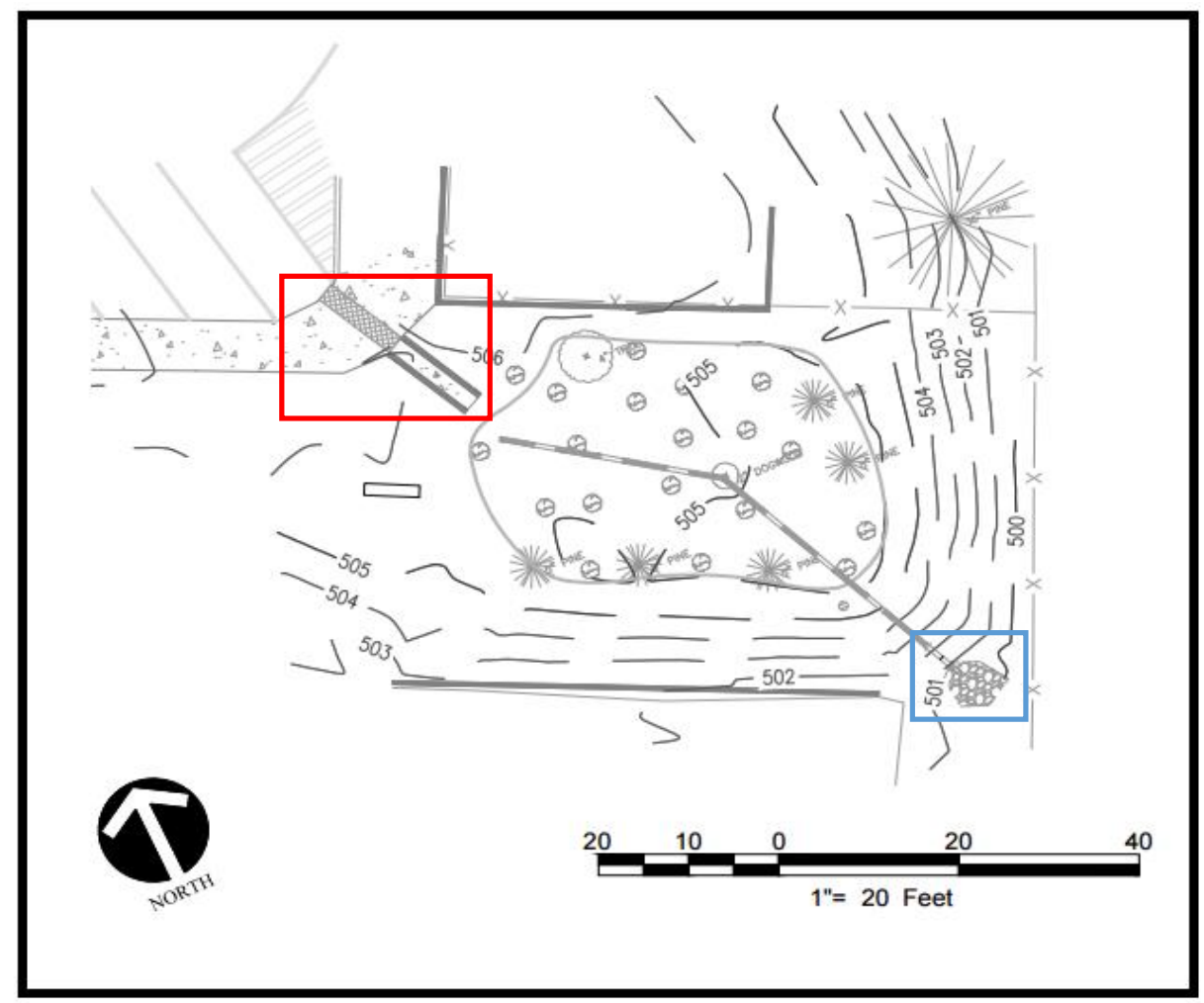

Figure 3. Plan view of the Venable Elementary bioretention facility. Inlet channel enclosed in red, outlet area in blue. Contours indicated by elevation in feet. (modified from Ecosystem Services LLC 2015) 
In July of 2015, the system was retro-fitted for this study. The old media was excavated and replaced with an enhanced media. Figure 4 is a picture taken during retro-fit construction as the top layer of media is being placed.

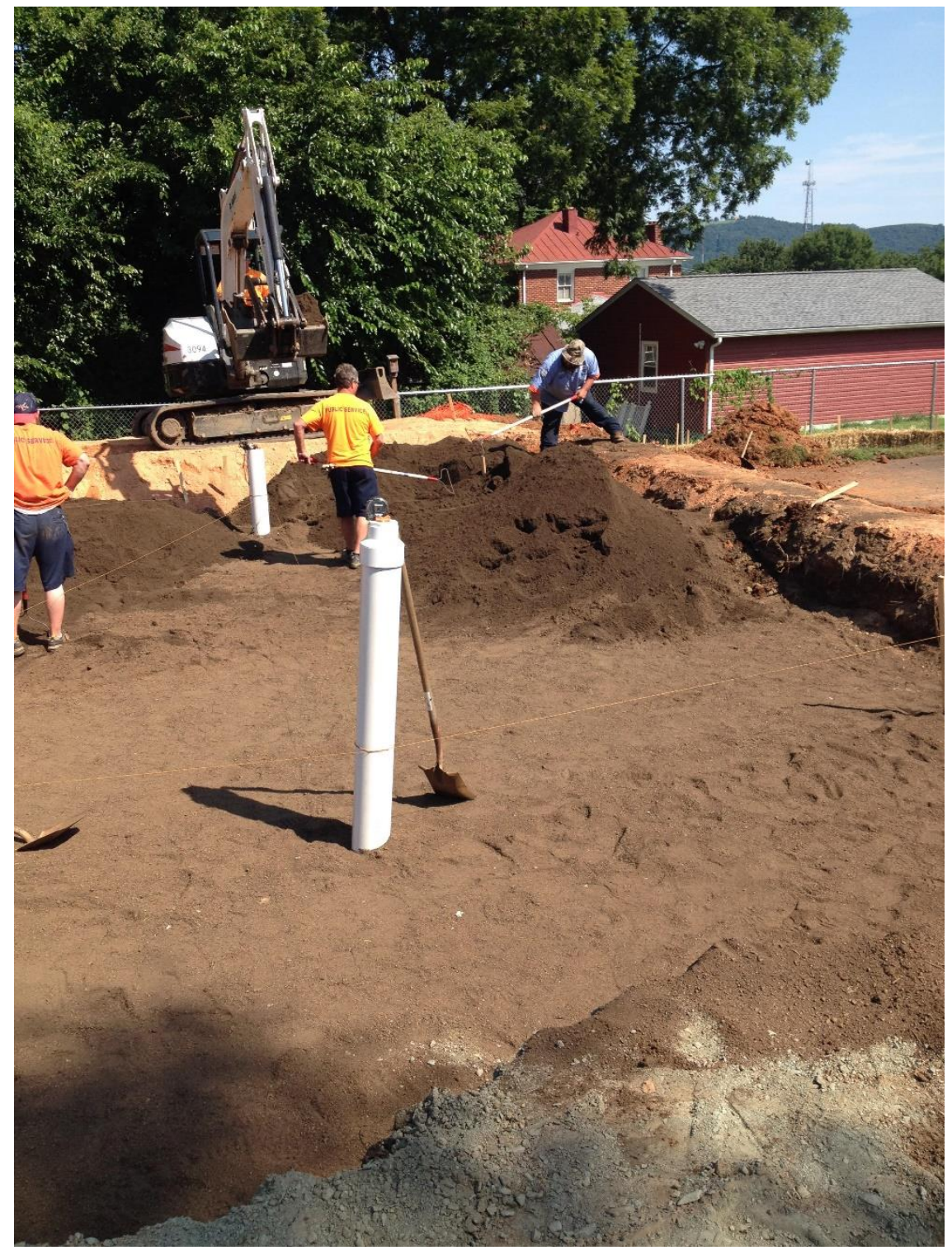

Figure 4. Venable Elementary bioretention during retro-fit construction

As part of the retrofit, the drainage system was adapted to an internal water storage system. The new outlet pipe was raised and attached to the far PVC stand pipe (figure 4). The new media contained biochar, zero-valent iron (ZVI) and luck biofilter. Luck biofilter is a media created by Luck specialty products specifically for use in BMPs. The luck media contains $88 \%$ 
sand, 7\% silt and 5\% clay, as well as 3\% organic material (Luck Specialty Products). ZVI, 8/50 size, was purchased from Peerless Metals. Biochar was purchased from the Biochar Company. There is $2.5 \mathrm{ft}$. $(.76 \mathrm{~m})$ of bioinfiltration media at the Venable site. The top $1.5 \mathrm{ft} .(.45 \mathrm{~m})$ is a mixture of biochar and luck media (biochar layer), $86 \%$ Luck Media and 14\% biochar by bulk volume. The bottom $1 \mathrm{ft} .(.30 \mathrm{~m})$ is a mixture of biochar, luck media and ZVI (biochar/ZVI layer), $81 \%$ Luck Media, $14 \%$ biochar, and 5\% ZVI. Below the two and a half feet of media is a 6inch perforated outlet pipe surrounded by gravel. Figure 5 depicts these elements in the section view of the bioretention filter. For this system, the ZVI, at $\$ 900$ per net ton, cost $\$ 4710$ including shipping. The biochar, at $\$ 395$ per 4 cubic yards, cost $\$ 2310$ including shipping.

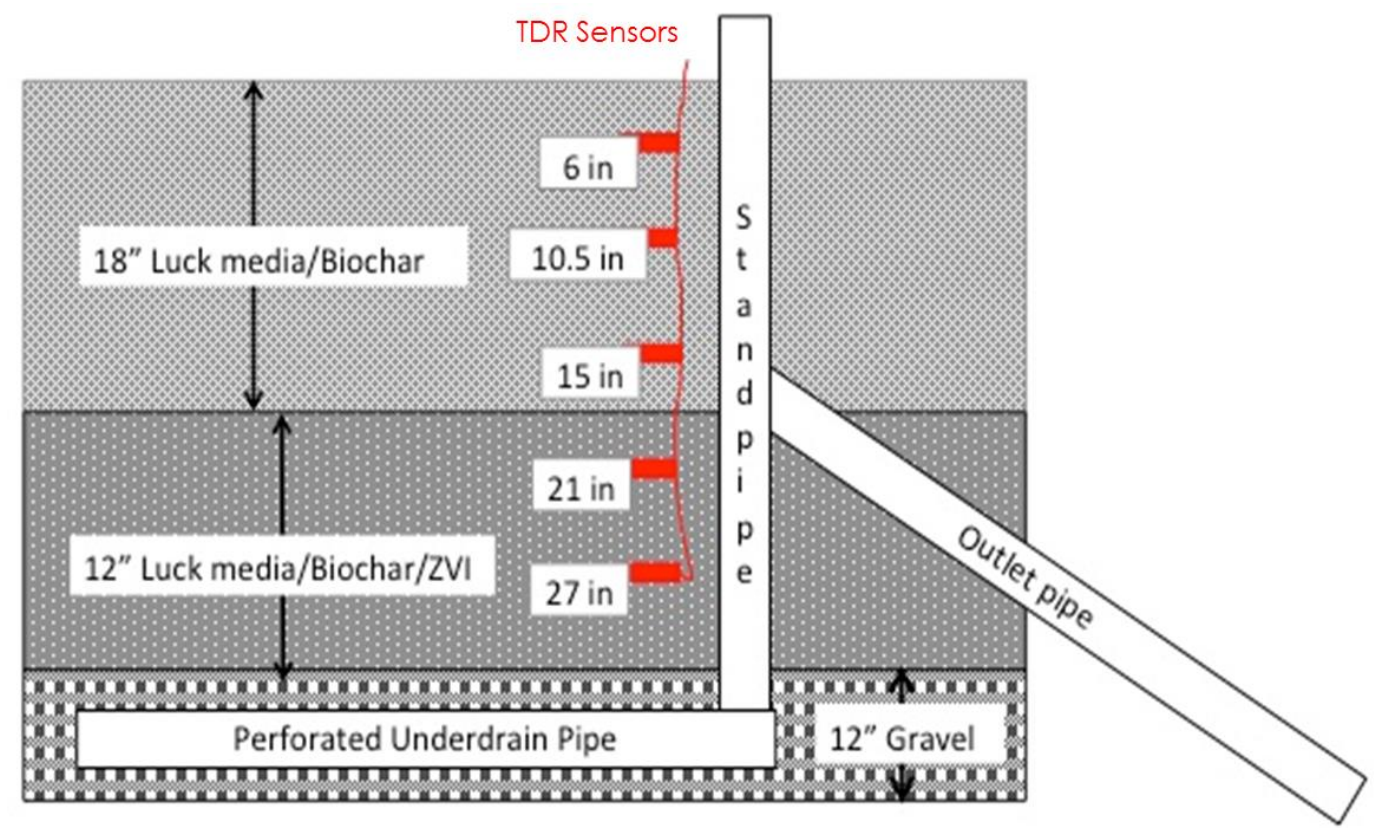

Figure 5. Section view of the Venable elementary bioretention filter.

During the retrofit, two stand pipes were attached to the original outlet pipe, seen in figure 4 and 5. The internal water storage system was created by attaching the new 6 in. PVC outlet pipe to the stand pipe $1 \mathrm{ft}$. above the old outlet pipe. This requires the water to fill the $1 \mathrm{ft}$. depth before outflow begins and helping to keep the $\mathrm{ZVI} /$ biochar layer of media saturated. 


\subsection{Field Equipment}

\subsubsection{Primary and Secondary Flow Devices}

Primary measurement devices for open channel flow include weirs and flumes (US Department of the Interior Bureau of Reclamation 2001). From June 2015 to June 2016, the inlet channel used a V-notch weir as the primary device, and from June 2016 to present, the inlet channel used a $60^{\circ} \mathrm{XL}$ trapezoidal flume. Figure 6 shows the V-notch weir and the XL trapezoidal flume in the inlet channel.

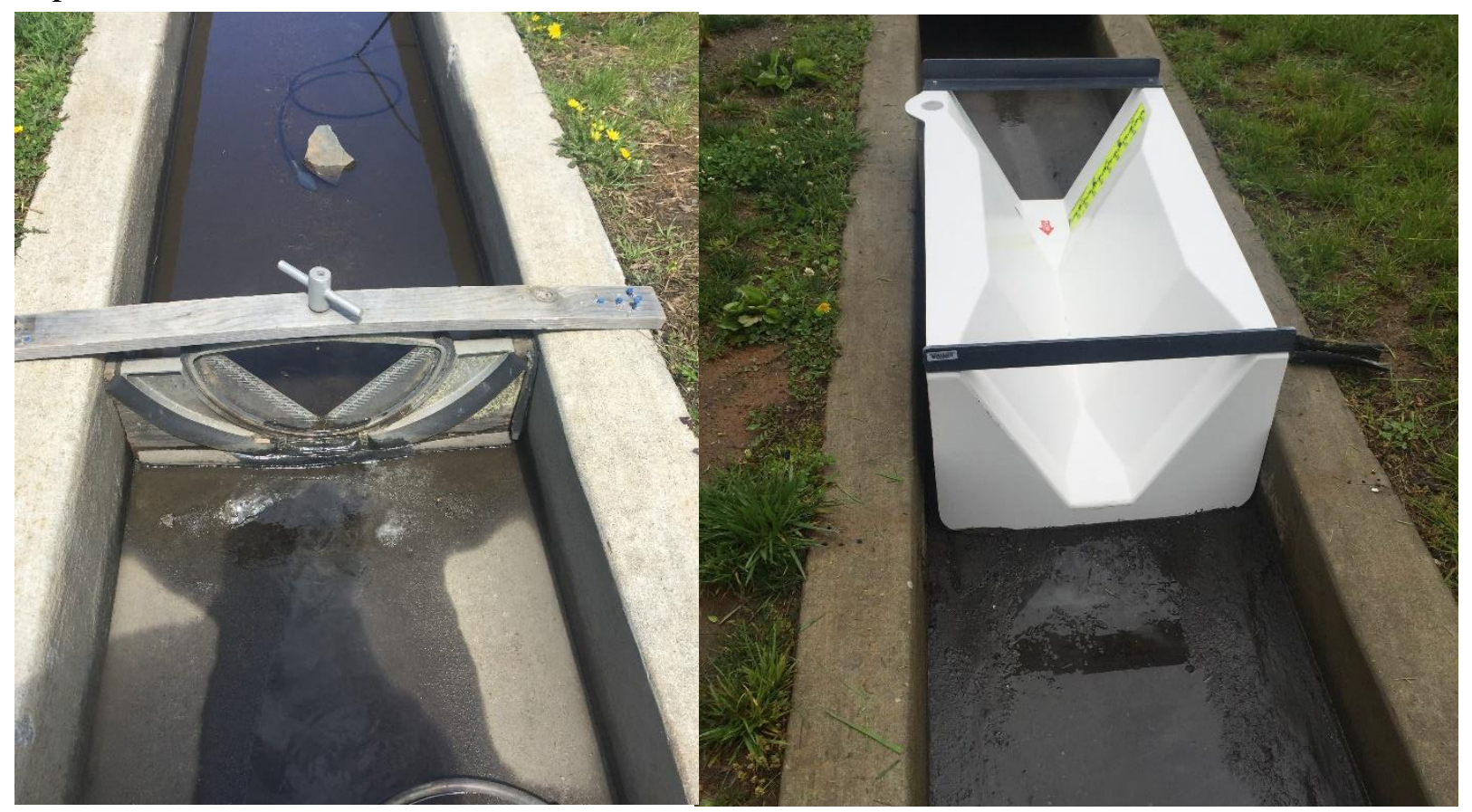

Figure 6. The V-notch weir (left) and $600 \mathrm{XL}$ trapezoidal flume (right) in the concrete channel, picture taken from downstream facina upstream

The primary devices require secondary devices in order to measure the water depth. A pressure transducer was used for both devices. The pressure transducers determines the depth of water based on the pressure above the sensor. Two pressure transducers were used. One pressure transducer was connected to the Hach Sigma 900Max Portable Samplers, which were used for sampling. For the v-notch weir, the transducer was placed a distance of 4 times the maximum head upstream of the weir (US Department of the Interior Bureau of Reclamation 2001). The 
Hach pressure transducer can be seen above the weir in figure 6. For the trapezoidal flume, the transducer hung in the stilling well on the left, upstream (figure 6). A Solinst levellogger 3000 series was used as a secondary pressure transducer in the stilling well. The Levelogger, which measures the pressure above the sensor, is accompanied by a Barologger which records the barometric pressure and corrects the pressure measured by the Levelogger. The Barologger should be installed outside within a 20 mile radius of the Levelogger site.

From June 2015 to June 2016, t he outlet primary flow device was a 6 in. PVC pipe, from and from June 2016 to present a .6" HS flume was used. Figure 7 depicts the outlet primary flow devices. The outlet pipe had an attached stilling well where both the Hach Sigma 900Max Portable Sampler pressure and a Solinst pressure transducer were hung to measure the depth of water in the pipe. Similarly, the flume had a built-in stilling well for the transducers.



Figure 7. the outlet 6in PVC pipe with stilling well (left) and .6 HS flume (right) 
Flow was calculated based on the depths measured by the pressure transducer. The vnotch weir equation used to calculate flow is shown in equation 3.

$$
Q=2.49 H^{2.48}
$$

Where, $Q$ is the discharge, and $H$ is the head. For a v-notch weir, the head is measured as depth above the crest. This effectively comes from the base equation of a v-notch weir, equation 4.

$$
Q=\frac{8}{15} * C * \sqrt{2 g} * H^{\frac{5}{2}}
$$

Where $C$ is .58 and $g$ is gravity in feet $\left(32.2 \mathrm{ft} / \mathrm{s}^{2}\right)$ (Munson 2009). Determining flow through a pipe is much more difficult. Flow rate was measured based on Manning's equation, equation 5.

$$
Q=v A=\left(\frac{1.49}{n}\right) A R^{\frac{2}{3}} \sqrt{S}
$$

where, $v$ is velocity, $(\mathrm{ft} / \mathrm{s}), A$ is Flow Area, $\left(\mathrm{ft}^{2}\right), n$ is Manning's Roughness Coefficient, $R$ is Hydraulic Radius, (ft) and $S$ is Channel Slope, $(\mathrm{ft} / \mathrm{ft})$. The complicating factor is that Mannings roughness coefficient (n), which is usually seen as constant, actually changes with depth in the pipe (Akgiray, 2004). Table 1 shows the Escritt table, which relates Q/Qmax and D/Dmax (where $\mathrm{D}$ is depth of flow) given the rate of change in $\mathrm{n}$. Through some experimenting Qmax was determined to be $440 \mathrm{gpm}$ for our system . 
Table 1. Escritt table (Akgiray, 2004)

\begin{tabular}{|r|r|}
\hline d/dmax & \multicolumn{1}{|l|}{ Q/Qmax } \\
\hline 0 & 0 \\
\hline 0.1 & 0.0176 \\
\hline 0.2 & 0.0725 \\
\hline 0.3 & 0.1621 \\
\hline 0.4 & 0.2808 \\
\hline 0.5 & 0.4213 \\
\hline 0.6 & 0.5747 \\
\hline 0.7 & 0.7301 \\
\hline 0.8 & 0.8738 \\
\hline 0.9 & 0.9853 \\
\hline 1 & 1 \\
\hline
\end{tabular}

Flume installation allowed for much simpler flow calculations. Depths were directly related to flows in a chart specific to each flume. The table of values relating $Q$ to $D$ was taken from Open Channel flow, the company that built the flumes.

\subsubsection{Sampling System}

The sampling devices used at Venable were Hach Sigma 900Max Portable Samplers. One sampler was placed at the inlet and one was placed at the outlet. Each sampler contained 24, 1 liter sampling bottles in the base. Each bottle was stuffed with plastic Whirl-pak bags for sample collection. Therefore bottles did not require acid washing between storms. The sampler runs on a 12 volt dc battery. Each sampler had a pressure transducer linked to it, as well as, a sampling tube. The outlet sampler was fit with a tipping bucket rain gauge to track rainfall at the site. The sampling tube is a $27-\mathrm{ft}(8.22 \mathrm{~m})$ long, $3 / 8$ " plastic tube that is placed downstream of the transducer during an event. When sampling is triggered the sampler creates suction through the plastic hose, and the internal distributor displaces the water into one of the sampling bottles. The first sample of an event was collected after an increase in depth was detected by the pressure 
transducer. For subsequent samples, the samplers were programmed to collect samples after a specified volume of stormwater had been flowed by. This constant volume was adjusted for each event, based on the predicted depth of the event. The data about the event (depths as measaured by the Hach transducers, volumetric flows as calculated based on the type of primary device, time of sample collection, and rainfall depth) is stored in the sampler memory. After each event, data was downloaded using the USB connection and Insight software specific to the Hach Samplers.

\subsection{Event Procedures}

\subsubsection{Standard Event Procedures}

Before every storm event, a set of steps was taken to prepare to collect samples. If the chance of rain was above $50 \%$, then storm preparation could commence. Storm depths around 1 inch were the target for collection. Following Virginia specifications (VA DEQ 2011), a 1-inch storm is the design standard for the bioretention system. Approximately $1 \mathrm{in}$. of rainfall is the $90^{\text {th }}$ percentile of rainfall events in Virginia, and used as the design storm because it represents a majority of the runoff (VA DEQ 2008). Before each storm, ice packs are put in the samplers to keep samples chilled. The sampling regime is initiated on the sampler, making sure proper trigger depth and the volume for sampling pacing are entered. The transducers are checked and put in proper position if not so already. After the storm event, samples were picked up within 24 hours of sampling, and nutrient analysis was performed within 48 hours of a sample collection. Sample date and times are recorded from the sampler, and data is downloaded. The samples are brought back to the lab and refrigerated until analysis. 


\subsubsection{Artificially Increased Influent Concentration Procedure}

In order to guarantee higher inlet concentrations, phosphate and nitrate were added to the inlet of the 3/31/17 storm. Solution was made with sodium nitrate $\left(\mathrm{NaNO}_{3}\right)$ and potassium phosphate $\left(\mathrm{KH}_{2} \mathrm{PO}_{4}\right) .23 .56$ grams of $\mathrm{KH}_{2} \mathrm{PO}_{4}$ and 21.32 grams of $\mathrm{NaNO}_{3}$ was added to a 5gallon bucket filled with DI water, so that spiking fluid has a concentration of approximately $1.25 \mathrm{~g} / \mathrm{L}$ of $\mathrm{KH}_{2} \mathrm{PO}_{4}$ and $1.13 \mathrm{~g} / \mathrm{L}$ of $\mathrm{NaNO}_{3}$. The bucket had a rubber hose attached to the bottom controlled with a stopcock. Near the start of the event, the stopcock was set to slowly drip the solution into the inlet above the sampler.

\subsection{Nutrient and TSS Analysis}

Four nutrient analyses were completed: phosphate, total phosphorous, nitrate and total nitrogen. A minimum of 4 samples from both the inlet and the outlet had to be analyzed. The measured concentration for analyzed samples was used as a representation for a portion of total volume of water. Samples were chosen so each concentration best fit its representative volume. A sample could not represent more than $40 \%$ volume of a storm.

Hach test kits were used for all nutrient analyses. Total nitrogen was measured using TNT Persulfate Digestion Method (0.5 to $25.0 \mathrm{mg} / \mathrm{L} \mathrm{N}$ ) (Hach Method 10071, 2014). Nitrate concentration was measured using Nitrate TNT 835 (.23 to $13.50 \mathrm{mg} / \mathrm{L}$ NO3-N)(Hach TNT plus Method 10206, 2015). Reactive phosphate was measured using the TNT 843 (.05 to $1.50 \mathrm{mg} / \mathrm{L}$ PO4-P) (Hach Method 10209, 2016). Total phosphorus measurements used the same test kit as for phosphate (TNT 843) with a modification of method that included a 1-hour digestion step in a Hach DRB200 test tube reactor (Hach Method 10210,2016). Sample blanks were taken for phosphate concentrations to account for turbidity (Hach Method 10209, 2016). Reaction 
intensity from all test kits were read in the Hach DR-3900 spectrophotometer and concentrations recorded. Method validation of all tests is shown in appendix A. Total suspended solids (TSS) was measured for each sample collected. The ASTM standard measurement method for TSS in water was used (ASTM 2000). A Whatman 934-AH glass microfilter was dried and weighed. It is placed on the vacuum pump. The vacuum pump pulls the water through the filter leaving solids. The filter is then dried at $105^{\circ}$ for 24 hours, and re-measured.

Load and EMC were calculated for the inlet and outlet based on Equation 2.

Representative volumes for nutrients and sediments were determined separately, since typically the number of samples analyzed for each were not the same. The percent reduction is determined by equation 5 .

$$
\text { Percent Reduction }=\frac{\text { Inlet }- \text { Outlet }}{\text { Inlet }} * 100
$$

The load and EMC reduction along with volume and peak flow reduction are used to quantify the BMP performance.

\subsection{TDR Data}

At the Venable enhanced bioretention facility, 5 time domain reflectometer (TDR) sensors are installed to measure soil moisture. The sensors are installed at different vertical levels within the BMP. The location and depths of the sensors can be seen in figure 5. The TDR measures volumetric water content by sending out electric pulses. The water content is calculated based the time it takes the electric pulse to reflect back to the sensor. The sensors were calibrated based on specific bulk density; the bulk density of the top sensor is different from the 
bulk density of the bottom sensor. The calibration related the level of saturation, which was measured using field data, and the millivolts measurement used by the TDR. Once related a calibration curve was created that took all millivolt measurements and calculated volumetric water content. The sensors were used to determine the saturation levels in the ZVI/biochar/luck media layer, which should stay well saturated all the time.

\subsection{Results}

\subsection{Storm Events Overview}

A total of 13 storms were collected; other storms were not analyzed due to complications, which are discussed in chapter 5. Seven storms were captured after the media enhancements were installed, and 6 storms were captured before construction. One of the post- enhancement storms analyzed did not have any outflow, see Appendix B; and another storm used synthetically increased influent concentrations, see section 4.4. Five post-enhancement storms were captured and analyzed for performance of the bioinfiltration system under natural conditions. Table 2 contains rain information for these 5 storms, along with the primary flow device mentioned in section 3.1 . 
Table 2. Rain Data for 5 post-enhancement natural storms

\begin{tabular}{|c|c|c|c|c|c|c|}
\hline $\begin{array}{l}\text { Event } \\
\text { DATE }\end{array}$ & $\begin{array}{l}\text { Primary } \\
\text { Devices }\end{array}$ & $\begin{array}{l}\text { Total Rain } \\
\text { Depth (in) }\end{array}$ & $\begin{array}{c}\text { Total Rain } \\
\text { Duration } \\
\text { (hrs) }\end{array}$ & $\begin{array}{l}\text { Avg. Rain } \\
\text { Intensity } \\
\text { (in/hr) }\end{array}$ & $\begin{array}{c}\text { Max } \\
\text { Intensity } \\
\text { (inch/hr) }\end{array}$ & $\begin{array}{l}\text { Antecedent } \\
\text { Dry Days }\end{array}$ \\
\hline $9 / 30 / 15$ & Pre-Flumes & 2.8 & 8.33 & 0.34 & 4.08 & 0.61 \\
\hline $11 / 9 / 15$ & Pre-Flumes & 1.11 & 21.91 & 0.05 & 0.60 & 1.91 \\
\hline $4 / 7 / 16$ & Pre-Flumes & 0.75 & 3.25 & 0.23 & 0.72 & 9.91 \\
\hline $6 / 17 / 16$ & Flumes & 1.12 & 3.58 & 0.31 & 2.04 & 11.55 \\
\hline $9 / 27 / 16$ & Flumes & $0.87^{1}$ & 8.51 & 0.10 & 0.44 & 7.29 \\
\hline Average & & 1.32 & 9.12 & 0.21 & 1.58 & 6.25 \\
\hline
\end{tabular}

Each storm is referred to by the date the event occurred. Three storms were captured before the flumes were installed, and 2 were captured after the flumes were installed. The flumes allowed for easier and more reliable flow calculation; unfortunately, there have been fewer acceptable storms since their installation given extended dry periods (as discussed more in Chapter 5).

Of the 5 natural storms with outflow, each, except 9/30/15, had a rain depth around 1 in. $(25.4 \mathrm{~mm})$ (Table 3), which is the design storm size. 9/30/15 had a rain depth of 2.8in over 8.33 hours, which according to the National Oceanic and Atmospheric Administration (NOAA) Precipitation Frequency Data Server is about a 2-year storm, and is in the top 10 percentile for rainfall events in Virginia. Other storms in Table 2 were smaller than a 1 year storm.

\footnotetext{
${ }^{1}$ This depth information is from Scott Stadium Rain Gauge.
} 
Figures $8-12$ are the hyetographs and inlet and outlet hydrographs for each of the 5 storms in Table 2. These hydrographs and hyetographs are good depictions of how the BMP is functioning hydrologically during large storms. As can be seen in Figures 8-12, the inflow rates directly reflect the timing and intensity of the rain. Figure 13 plots the total volume of inflow against the depth of rain for each of the 5 storms. The total rain depth is directly proportional to the inflow volume.

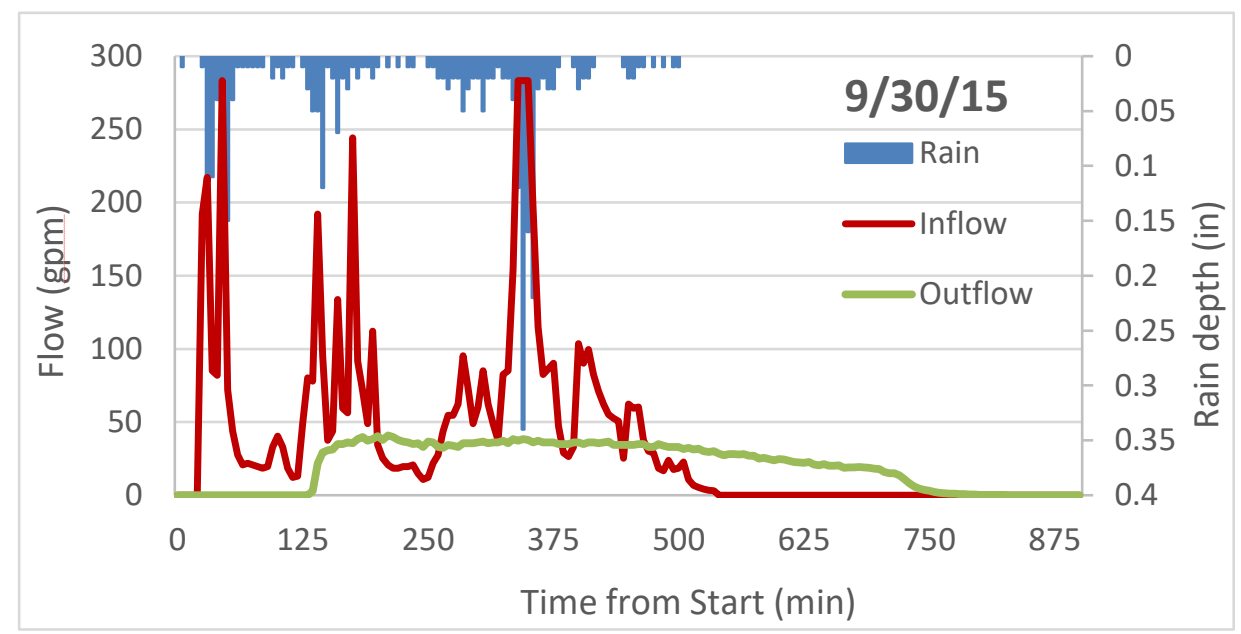

Figure 8. The hydrograph and hyetograph for the 9/30/15 


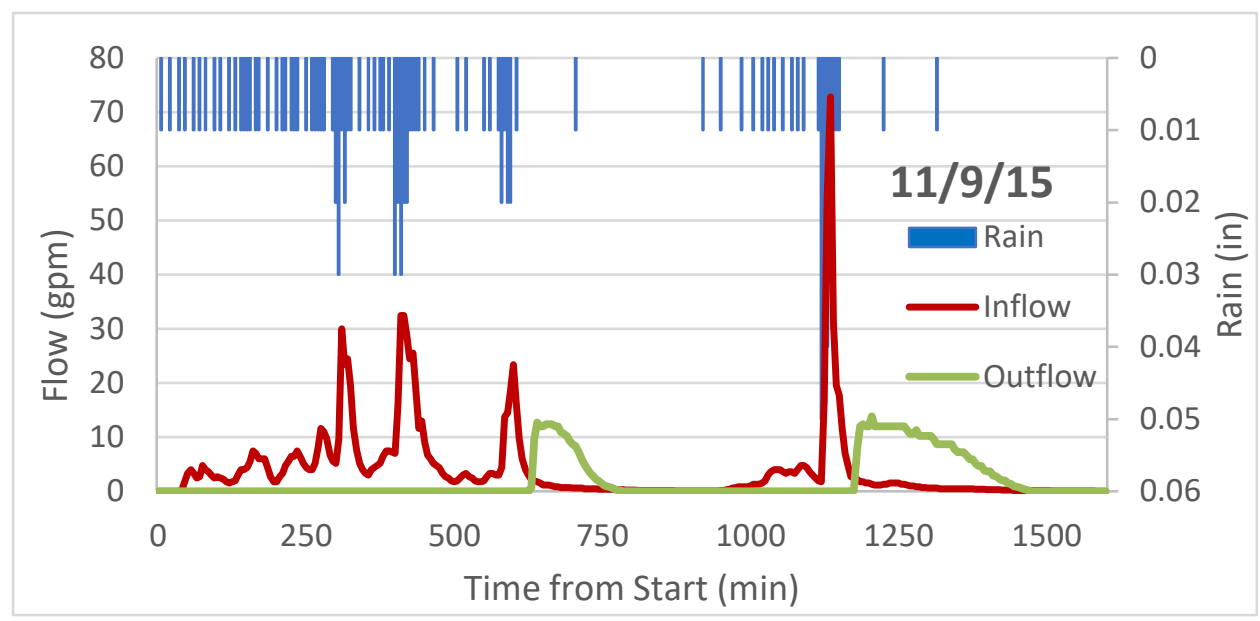

Figure 10. Hydrograph and hyetograph for the 11/9/15 storm

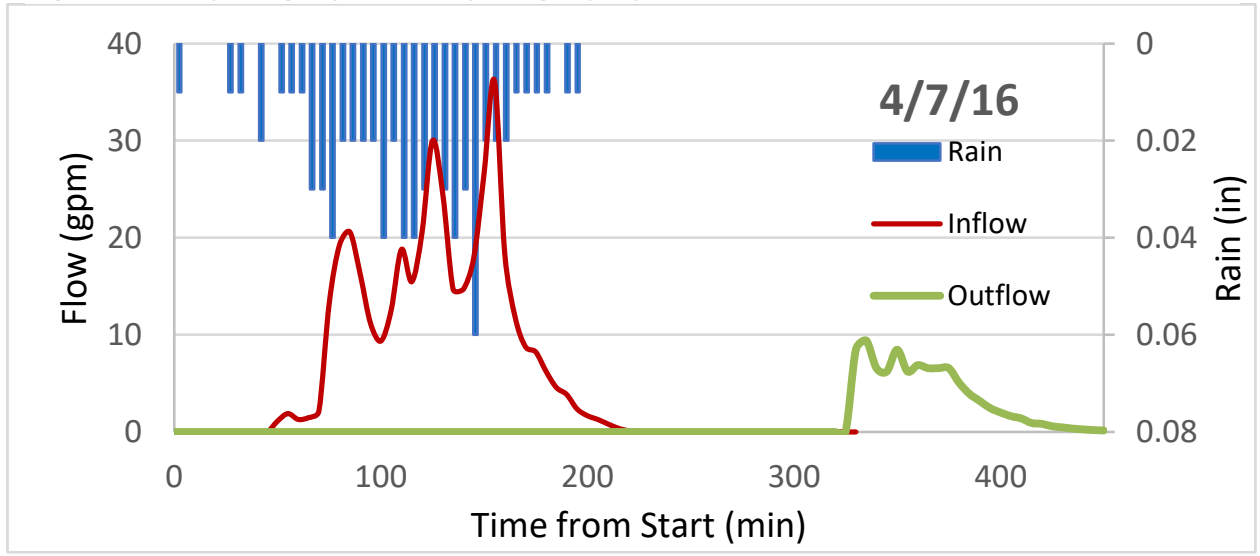

Figure 9. The hydrograph and hyetograph for the 4/7/16 storm

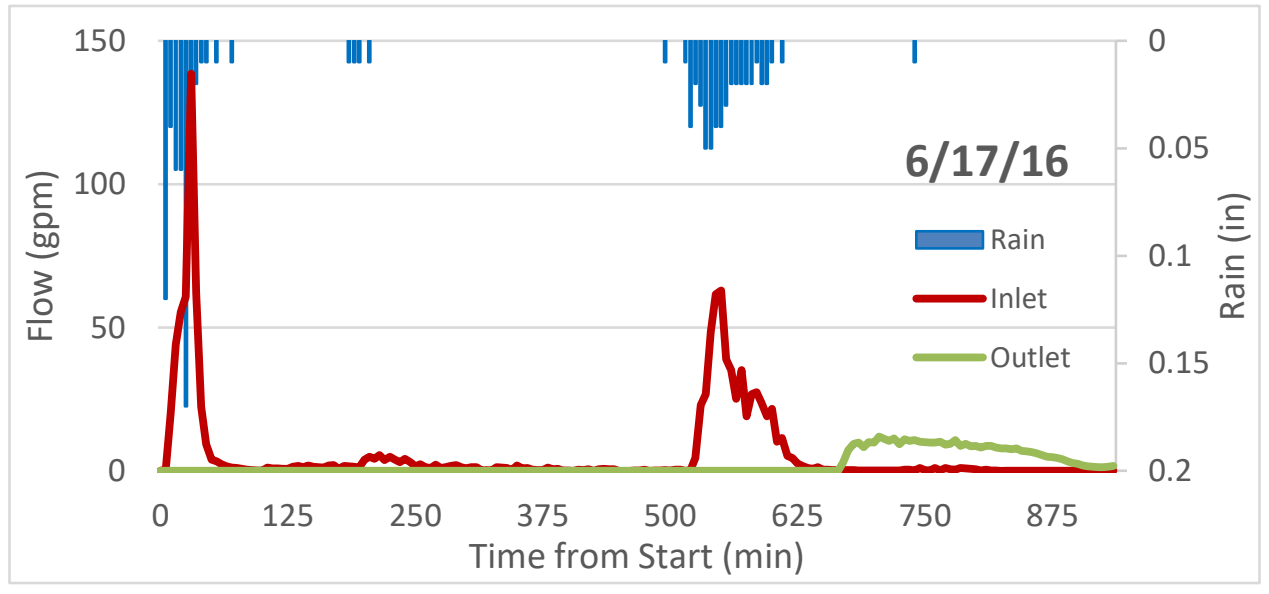

Figure 11. The hydrograph and hyetograph from 6/17/16 storm 


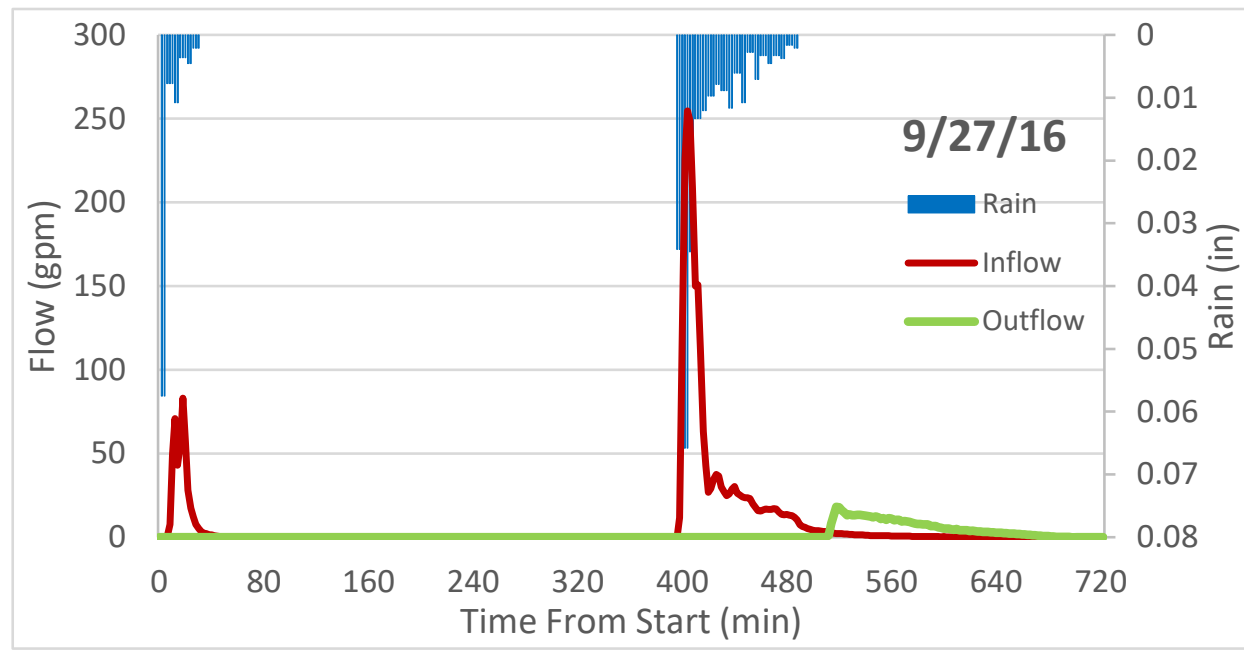

Figure 12. The hydrograph and hyetograph for the 4/7/16 storm



Figure 13. Rain Depth vs Inflow Volume

The outflow behavior is more difficult to predict. Typically, at least $0.5 \mathrm{in}$. $(12.5 \mathrm{~mm})$ of rain was necessary to generate outflow. For instances, inflow samples were collected for a 7/4/16 event, which had a rain depth of .43 in. (11mm), but no outflow occurred, (See Appendix B for a description of the 7/4/16 even.) The volume of outflow is correlated to the rainfall depth as seen in figure 14. The time until outflow begins varied widely between the events, as can be seen in Figures 8-12. 


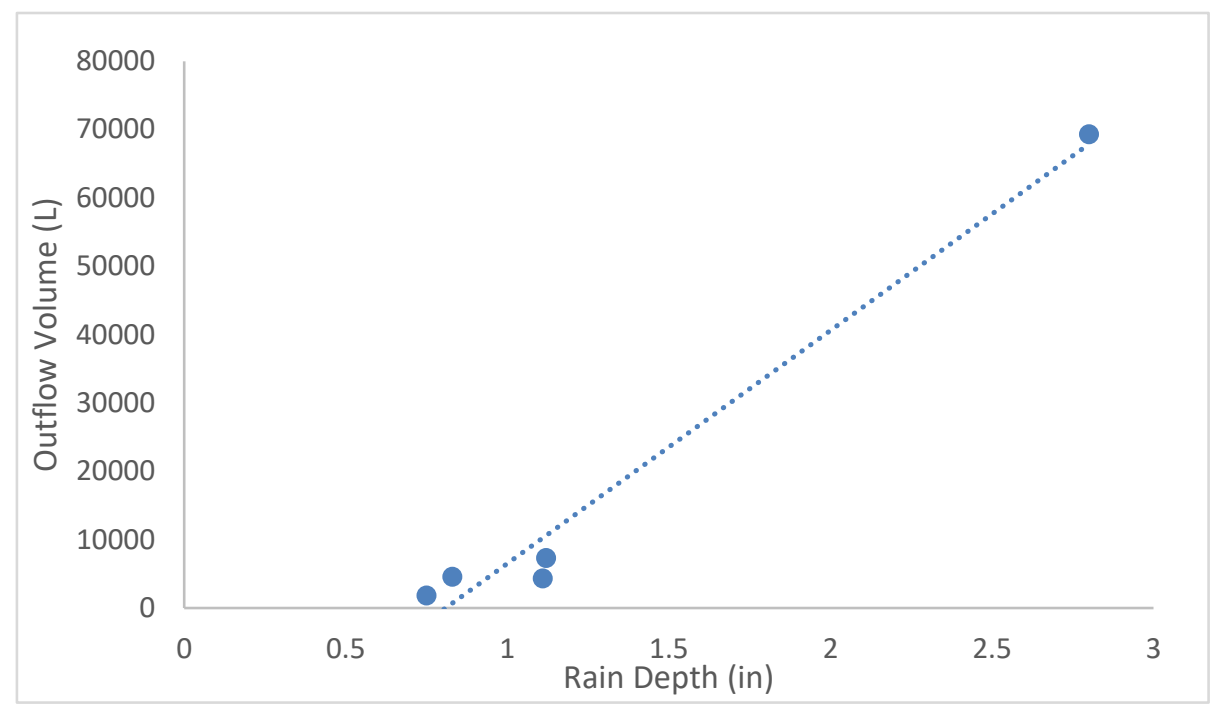

Figure 14. Rain depth vs outflow volumes

\subsection{Hydrologic Performance}

As stated in Chapters 2 and 3, an important part of BMP evaluation is volume and peak flow reduction. Figure 15 shows the percent reduction in volume and peak flow for the 5 major natural storms described in table 2.



Figure 15. Percent reduction of the volume and peak flow for 5 natural storms

The peak flow rate reduction was high with an average over the five storms of $87 \%$ reduction with three storms over $90 \%$ peak flow reduction. The overall volume reduction of the bioretention system was an average of $69 \%$ for the five storms. The only storm under $60 \%$ 
volume reduction was the very large 9/30/15 storm, which had a depth of 2.8 in (2.8 times greater than the design standard). The high volume reductions would indicate that the IWS layer is functioning well and there is infiltration to the ground. Storms under $0.5 \mathrm{in.}(12.5 \mathrm{~mm})$, which do not accumulate outflow, would achieve $100 \%$ volume and peak flow reductions, similar to the 7/4/16 storm (see appendix B). $60 \%$ of rainfall events in Virginia are $.5 \mathrm{in.}(12.5 \mathrm{~mm}$ ) or lower (VA DEQ 2008).

\subsection{Nutrient Analysis}

Nutrient and TSS reduction is the second measure of the effectiveness of a BMP. In the state of Virginia, there are standard percent reduction for total phosphorous (TP), total nitrogen (TN) for properly designed BMPs, given the level of the design as per the state design specifications (VA DEQ 2011). The level of a bioretention system is based on the size of the BMP, media depth, and underdrain (VA DEQ 2011). A level 1 BMP provides less reduction than level 2. The Venable Elementary bioretention system is built as a level 1 system. Table 3 states the functions of a bioretention system, as specified by the Virginia Department of Environmental Quality (VA DEQ 2014) for a level 1 and level 2 bioretention filter. 
Table 3 Bioretention functionc as specified in the (VA DEQ 2011)

\begin{tabular}{|l|c|c|}
\hline \multicolumn{1}{|c|}{ Stormwater Function } & Level 1 Design & Level 2 Design \\
\hline Annual Runoff Volume Reduction (RR) & $40 \%$ & $80 \%$ \\
\hline Total Phosphorus (TP) EMC Reduction & $25 \%$ & $50 \%$ \\
\hline Total Phosphorus (TP) Mass Load Removal & $55 \%$ & $90 \%$ \\
\hline Total Nitrogen (TN) EMC Reduction & $40 \%$ & $60 \%$ \\
\hline Total Nitrogen (TN) Mass Load Removal & $64 \%$ & $90 \%$ \\
\hline
\end{tabular}

Although the Virginia state design specifications do not state TSS removal efficiencies, effective estimates for TSS removal is provided by research done in conjuction with the EPA and the Chesapeake Bay program. Simpson and Weammert (2009) estimates 55\% load removal for bioretention with $\mathrm{C} / \mathrm{D}$ soils and an underdrain. EMC reduction is based on estimated influent EMCs from the Virginia Runoff Reduction method. Inlet EMCs are estimated as 1.86 and 0.26 $\mathrm{mg} / \mathrm{L}$ for TN and TP, respectively. The TSS inlfluent EMC for the United States estimated in the National Stormwater Quality Database is $58 \mathrm{mg} / \mathrm{L}$. The load and EMC values found at the Venable enhanced bioretention system for TP, TN and TSS at both the inlet and outlet are shown in tables 4 and 5. 
Table 4. EMC Values for 5 natural storms

\begin{tabular}{|r|r|r|r|r|r|r|}
\cline { 2 - 7 } \multicolumn{1}{c|}{} & \multicolumn{2}{c|}{ TSS (mg/L) } & \multicolumn{2}{c|}{ Total N (mg/L) } & \multicolumn{2}{c|}{ Total P (mg/L) } \\
\hline $\begin{array}{c}\text { Event } \\
\text { DATE }\end{array}$ & $\begin{array}{c}\text { Inflow } \\
\text { EMC }\end{array}$ & $\begin{array}{c}\text { Outflow } \\
\text { EMC }\end{array}$ & $\begin{array}{c}\text { Inflow } \\
\text { EMC }\end{array}$ & $\begin{array}{c}\text { Outflow } \\
\text { EMC }\end{array}$ & $\begin{array}{c}\text { Inflow } \\
\text { EMC }\end{array}$ & $\begin{array}{c}\text { Outflow } \\
\text { EMC }\end{array}$ \\
\hline $9 / 30 / 15$ & 32.3 & 5.4 & 1.1 & 2.0 & 0.05 & 0.02 \\
\hline $11 / 9 / 15$ & 3.4 & 10.7 & 0.3 & 0.9 & & 0.16 \\
\hline $4 / 7 / 16$ & 32.3 & 28.7 & 0.8 & 1.2 & 0.06 & 0.11 \\
\hline $6 / 17 / 16$ & 31.3 & 24.3 & 0.7 & 1.3 & 0.13 & 0.17 \\
\hline $9 / 27 / 16$ & 29.9 & 5.7 & 0.8 & 2.0 & 0.13 & 0.13 \\
\hline
\end{tabular}

Table 5. Load Values

\begin{tabular}{|c|r|r|r|r|r|r|}
\cline { 2 - 7 } \multicolumn{1}{c|}{} & \multicolumn{2}{c|}{ TSS LOAD (g) } & \multicolumn{2}{c|}{ Total Nitrogen (g) } & \multicolumn{2}{c|}{ Total Phosphorous (g) } \\
\hline $\begin{array}{l}\text { Event } \\
\text { DATE }\end{array}$ & \multicolumn{1}{c|}{ Load-in } & Load-out & \multicolumn{1}{c|}{ Load-in } & \multicolumn{2}{c|}{ Load-out } & \multicolumn{2}{l|}{ Load-in } & Load-out \\
\hline $9 / 30 / 15$ & 4071.2 & 285.8 & 136.3 & 93.1 & 6.18 & 1.11 \\
\hline $11 / 9 / 15$ & 79.3 & 46.0 & 7.0 & 2.7 & & .28 \\
\hline $4 / 7 / 16$ & 243.7 & 51.8 & 5.7 & 2.1 & .41 & .81 \\
\hline $6 / 17 / 16$ & 635.5 & 178.6 & 13.3 & 9.2 & 2.58 & .77 \\
\hline $9 / 27 / 16$ & 655.3 & 26.0 & 15.3 & 9.3 & 2.58 & \\
\hline
\end{tabular}

Figure 16 shows the reduction percentages for all five storms given the data from Tables 5 and

6. The EMC reductions were frequently negative. The lack of volume at the outlet probably created higher concentrations despite a reduction in mass. The only consistently positive EMC change was in TSS. The 11/9/15 storm, the only negative TSS EMC reduction, was most likely due to the low inlet EMCs. The load reductions were positive and more telling of the effectiveness of the BMP. Although low concentrations, the BMP was still achieving mass reduction, as shown in figure 16. 


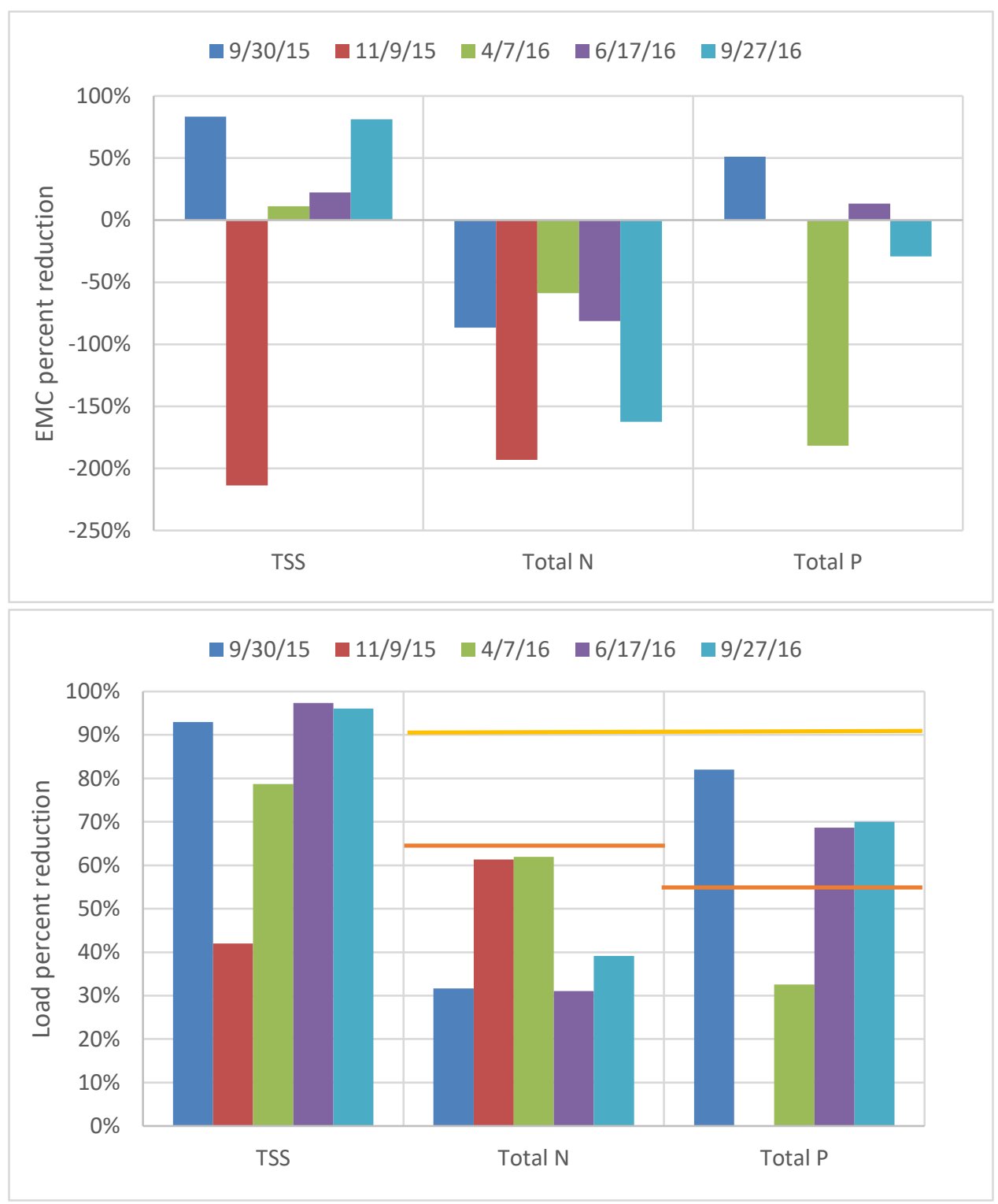

Figure 16. a) EMC reductions and b) load reductions on bottom at the Venable enhanced bioretention facility, level 1 and level 2 bioretention functions shown in orange and yellow, respectively

TSS load reduction was over $90 \%$ on three of the five storms and well above the estimated effectiveness of $55 \%$ for 4 of the 5 events. The 11/9/15 storm saw less TSS load removal, but had minimal inlet load. Total Phosphorous average load reduction over the 4 storms (Figure 16) was 63\%, above the level 1 standard. The total phosphorous load removal, although just above level 1 estimated efficiency, did not demonstrate enhancement beyond level 1specifications as anticipated. The total nitrogen removal efficiencies were consistently below 
level 1 estimated efficiency. With the enhanced system, it was hoped that removal rates would be closer to level 2 rates. Phosphate and Nitrate information for the 5 natural storms in Appendix B.

\subsection{Artificially Increased Influent Concentration}

In most storms collected, the phosphate levels at the inlet were below detection range. Concentrations for the other nutrient analyses were low and at times approached the lower limit of detection ranges, as well. The storm for which inlet concentrations were artificially raised, rain depth was 1.09 in $(27.7 \mathrm{~mm})$, close to the design storm depth. The inlet EMCs increased almost 10-fold. The total phosphorous inlet EMC was $1 \mathrm{mg} / \mathrm{L}$ and the total Nitrogen was .75 mg/L. Figure 16 shows the load and EMC reductions determined for 3/31/17 storm.

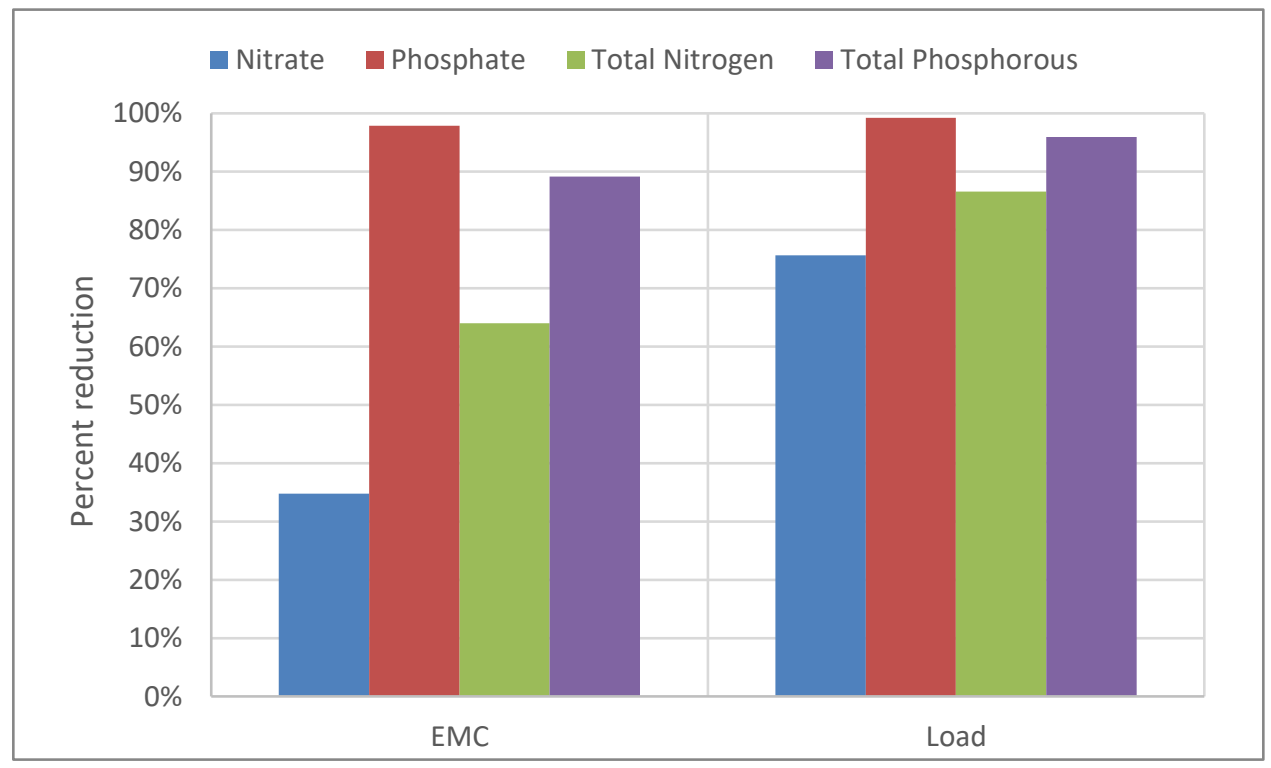

Figure 17. Nutrient load and EMC removals for 3/31/17 storm

This storm saw extremely high removal rates with phosphate EMC and loads removal approaching 100\% removal. The load removal rates surpass level 1 functions and approach level 2 functions, even for this 1" event. BMP functions are estimated by overall performance, averaging in storms with $100 \%$ removal. These results convey the possibility that poor removal rates are not due to complications with the enhanced system, but actually suggest the system is functioning more like a level 2 function. 


\subsection{Pre-Retrofit}

Before the ZVI and Biochar enhancements were added in late July of 2015, a number of storms were collected. Six pre-retrofit storms were captured. The information available for each of these storms varies from storm to storm. 4/25/15, 6/20/15 and 6/27/15 had enough data to do some analysis. These storms had rain depths of .34 inches, 1.09 inches and 1.47 inches, respectively.

The only storm with sufficient data to do a full load analysis was the 6/20/15 storm. $6 / 20 / 15$ event saw a $67 \%$ volume reduction and $72 \%$ peak flow reduction. Both attributes are below the average reduction after the retrofit. The $6 / 20 / 15$ event had good outflow, but there were complications with some of the nutrient testing. Despite complications nitrate, total phosphorous and TSS could still be measured. Table 6 shows the EMC concentrations and total masses at the inlet and outlet for Nitrate, Total Phosphorous and TSS.

Table 6. EMC and Loads 6/20/15

\begin{tabular}{|l|r|r|r|}
\hline EMC & Nitrate (mg/L) & $\begin{array}{c}\text { Total } \\
\text { Phosphorous } \\
\text { (mg/L) }\end{array}$ & TSS (mg/L) \\
\hline Inlet & 0.43 & 0.09 & 104 \\
\hline Outlet & 1.18 & 0.15 & 291 \\
\hline & Nitrate (g) & $\begin{array}{c}\text { Total } \\
\text { Phosphorous } \\
\text { (g) }\end{array}$ & \multicolumn{1}{|c|}{ TSS (g) } \\
\hline Load & 19.3 & 3.87 & 4421 \\
\hline Outlet & 6.2 & .78 & 1521 \\
\hline
\end{tabular}

The load reduction for nitrate, total phosphorous and TSS was $67.7 \%, 80 \%$ and $65.6 \%$, respectively. The EMC reductions were $-171 \%,-68 \%$ and $-188.9 \%$, respectively. The TSS load reduction was well below the average after enhancement, which was $80.4 \%$. The total phosphorous load reduction was actually higher than post-enhancement removals, and the nitrate 
removal was above the post-enhancement removal average of $45 \%$. The EMC reductions were close to the lowest EMC reductions seen after enhancement.

4/25/15 and 6/27/15 analysis was done on average concentrations. The 4/25/15 storm, only had two outlet values. These values were averaged. For the 6/27/15 storm, 5 samples were tested but flow rates were difficult to calculate because of equipment issues. Table 7 gives the average values at the inlet and outlet for each storm.

Table 7. EMC values for 4/15/15 and 6/27/15

\begin{tabular}{|c|c|c|c|}
\hline $\begin{array}{l}\text { 4/25/15 } \\
\text { Avg. }\end{array}$ & $\begin{array}{l}\text { Nitrate } \\
\text { (mg/L) }\end{array}$ & $\begin{array}{c}\text { Total } \\
\text { Phosphorous } \\
\text { (mg/L) }\end{array}$ & TSS (mg/L) \\
\hline Inlet & 1.0 & 0.36 & 105 \\
\hline Outlet & 1.9 & 0.29 & 266 \\
\hline $\begin{array}{l}\text { 6/27/15 } \\
\text { Avg. }\end{array}$ & $\begin{array}{l}\text { Nitrate } \\
\text { (mg/L) }\end{array}$ & $\begin{array}{c}\text { Total } \\
\text { Phosphorous } \\
\text { (mg/L) }\end{array}$ & TSS (mg/L) \\
\hline Inlet & 0.3 & 0.02 & 189 \\
\hline Outlet & 0.9 & 0.11 & 608 \\
\hline
\end{tabular}

Looking at the outlet versus inlet values, it appears that little treatment is occurring. In almost all cases, the concentrations at the outlet are higher than at the inlet. The TSS measurement at the outlet was biased due to the burial of the outlet. The outlet had been covered over with soil. Although we dug out the outlet, the high outlet concentrations may be due to the burial more than to the inlet load from a particular event. However, the inlet concentrations were also three times or more higher than what was observed after the enhancement. High TSS concentrations could lead to higher TP values. Thus, this data is not conclusive, but it does reveal that there were high concentrations at the outlet before enhancement. 


\subsection{TDR Data}

The time domain reflectometer (TDR) described in chapter 3 was used to measure the volumetric water content in the soil. Of the 5 sensors, the most important are the 2 sensors in the lower ZVI/Biochar/Luck Media layer. The intent is for this layer to remain saturated as part of the IWS layer. Figure 17 shows the percent saturation in the bottom soil layer over the first 4 months after installation. During rain events, the percent saturation would reach $100 \%$ for both sensors, but immediately after rain events the top sensor (blue line) would drop to below $80 \%$ saturation.

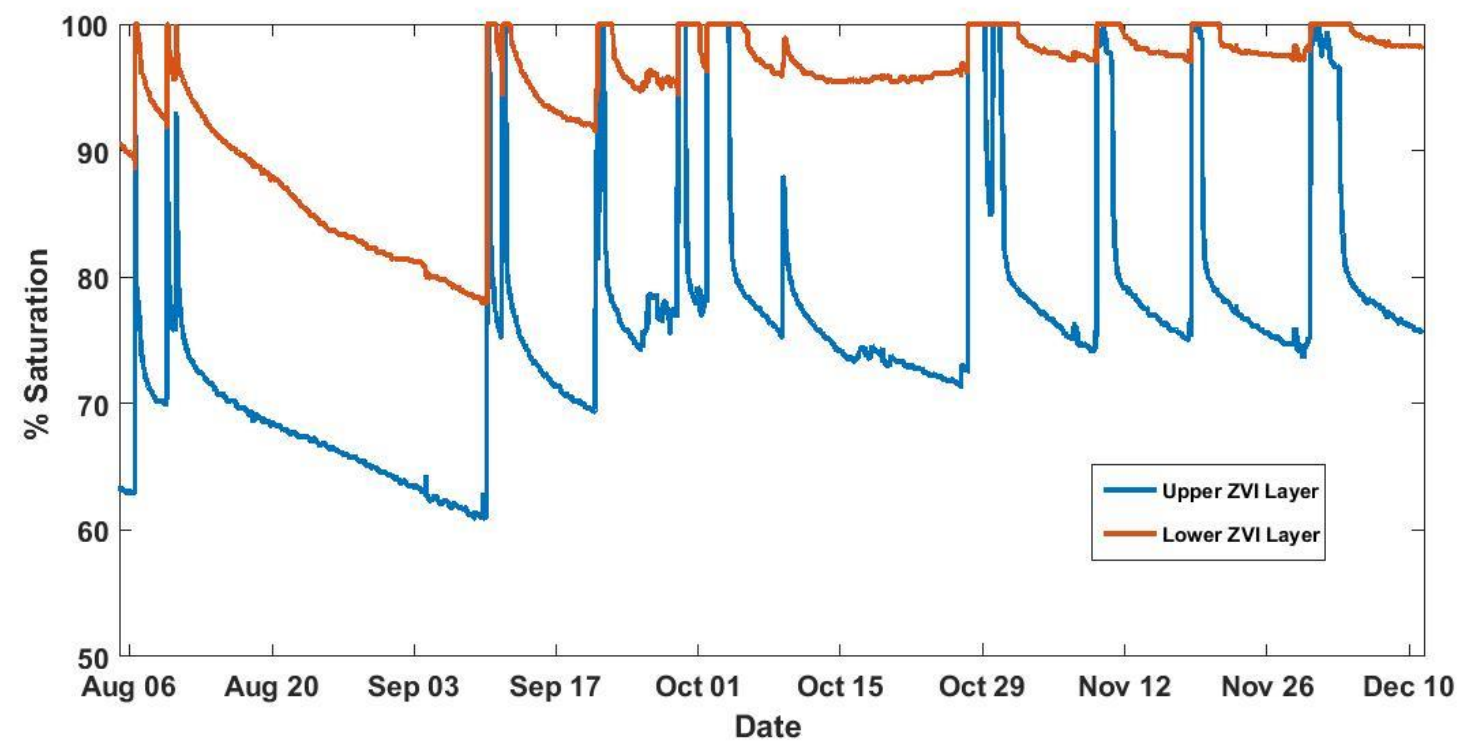

Figure 18. percent saturation of the ZVI/Biochar/Luck Media layer using TDR data 


\subsection{Discussion and Conclusions}

\subsection{Enhanced Bioretention Strengths}

The enhanced bioretention system functioned well hydrologically and with respect to sediment removal. A major characteristic in BMP evaluation is peak flow and volume reduction. The BMP saw good peak flow and volume reduction over all post-enhancement storms. Based on the results in figure 14, the enhanced system is allowing for significant volume reduction, above $60 \%$ during 1 inch storms, and peak flow reduction, above $70 \%$ on all monitored storms. This is likely due to the IWS layer added to the bioretention system . The IWS, as stated above, allows for maximum storage within the lower layers of the system before outflow. The increased storage facilitates more infiltration into the ground and negates effects of large storm runoff. These benefits may not be seen if larger storms occur closely spaced, when the subsoil would have less available storage, and more runoff could occur. We did not observe this effect due to the extended dry periods common during this study. The enhanced bioretention system exhibits high total suspended solids (TSS) removal. The TSS mass reductions post-enhancement have been high with 3 of 5 storms showing above 90\% TSS reduction. The pre-enhancement storm, $6 / 20 / 15$, had TSS load reduction of $65 \%$, which is below 4 of the 5 post-enhancement storms. The 11/9/15 storm which had TSS load reduction of about $40 \%$, had an inlet EMC of $10 \%$ of the inlet EMC's for all 4 other storms. Despite the flow volume and TSS reduction, the BMP is not having the same success with Total Nitrogen and Total Phosphorous removal.

\subsection{Possible Venable Bioretention Problems}

Based on the nutrient data from the enhanced bioretention system for the 5 natural storms, there is no evidence of the BMP demonstrating high nutrient treatment as hypothesized. 
Total nitrogen and total phosphorous levels did not reach reduction levels that would verify that the enhanced bioretention media is better than the standard media. There could be a number of reasons the BMP is not working as hypothesized. One of the possible problems with the BMP is the saturation level of the bottom soil layer. Figure 17 shows the saturation levels of the bottom layer determined from the TDR data. The decrease in saturation could be a possible mistake in construction. The design assumed a 6 inch $(12.5 \mathrm{~mm})$ capillary fringe, which was seen in lab studies (Chiu \& Imhoff, 2014). However, this capillary fringe may not have occurred, as suggested by the TDR data in figure 17. Saturation may have been lost due to the surrounding soil type. The soil type for the site was estimated as hydrologic soil group C. The use of IWS with hydrologic soil group C is relatively unknown (Brown et al., 2009) The lack of saturation of the ZVI layer could decrease the function of the BMP.

The most likely reason behind the apparent lower nutrient removal rates at the Venable enhanced bioretention system is the low concentrations of pollutant in the influent to the system. The concentrations at the inlet are too low to see good reduction percentages. Low concentrations in stormwater may be difficult to reduce any further even for properly performing BMPs; this is referred to as the irreducible concentration (Strecker et al., 2001). The irreducible concentration is usually the product of internal microbe production or bad reduction pathways with in the BMP (Schueler and Holland 2000). The numbers considered irreducible are different for different BMP sites. Larm and Hallberg 2008 found the irreducible concentration for phosphorous to be $0.10-0.15 \mathrm{mg} / \mathrm{L}$ and $20-40 \mathrm{mg} / \mathrm{L}$ for TSS. Another study in Watershed Protection Techniques (1995) found total phosphorous irreducible concentrations to be .15-.20 $\mathrm{mg} / \mathrm{L}$ and total nitrogen irreducible concentrations of $1.9 \mathrm{mg} / \mathrm{L}$ (Irreducible Pollutant Concentrations Discharged from Stormwater Practices 1995). Looking at the EMC's for the 5 
storms after enhancement, the inlet concentrations are near or below these irreducible concentrations, table 8 shows the concentrations including the Virginia Runoff Reduction method estimated influent EMCs.

Table 8. Influent EMCs (Collected EMCs, Irreducible EMCs, VRRM EMCs)

\begin{tabular}{|l|c|c|c|}
\hline & $\begin{array}{l}\text { Maximum } \\
\text { EMC }\end{array}$ & $\begin{array}{l}\text { Irreducible } \\
\text { Concentrations }\end{array}$ & $\begin{array}{l}\text { Estimated } \\
\text { Influent } \\
\text { EMC } \\
\text { (VRRM) }\end{array}$ \\
\hline Nitrogen (mg/L) & 1.1 & 1.9 & 1.86 \\
\hline $\begin{array}{l}\text { Phosphorous } \\
\text { (mg/L) }\end{array}$ & 0.13 & $0.10-0.20$ & 0.26 \\
\hline TSS (mg/L) & 32 & $20-40$ & 58 \\
\hline
\end{tabular}

The results from the spiked storm (figure 16) increased the inlet concentrations above the irreducible levels, and the reduction rates for this storm were very high. This would suggest that we were unable to observe the removal performance of this BMP due to the low inlet concentrations observed at the Venable Site.

\subsection{Monitoring and Analysis Challenges}

\subsubsection{Equipment}

There were a number of challenges in the monitoring and analysis of the bioretention system that made research difficult.. Before each event equipment had to be prepared and calibrated for the storm, and if this was done incorrectly, then a storm could be missed.

Several components of the sampling system were prone to malfunction. One such component is the pressure transducer, which measured depth and ultimately flow for the sampler. If the transducer was reading too low, the sampler would not sample when necessary; conversely, if the transducer was reading too high the sampler could sample too often and 
potentially fill up before the storm ended. Before the installation of the flumes, the transducer was placed in the dry channel. Because the transducer was starting in a dry location, depths were difficult to calculate. The depth is measured above the transducer head, so the 0 point was difficult to find. The transducer's locations was also open and unsecured in the center of the channel. During a couple of the storms (not used in this study) the transducer was moved or turned over, ruining depth calculation. The installation of the flumes helped assuage the transducer and flow calculation problems.

The flume installation allowed for the transducers at both the inlet and outlet to be in a more favorable position in a stilling well. The Solinst transducers are much more accurate and reliable, and allowed for comparison to the Hach transducer. The flumes, also, greatly helped in flow calculation. Before flume installation, the Hach transducer measured the total depth of flow upstream of the weir (including any inaccuracies inherent in the Hach readings). These transducer measurements then had to be corrected to find the depth of flows over the weir, adding to the possibility of error. It was difficult with this system to maintain the level of accuracy to have confidence in the flow rates over the weir. The equation for flow through a pipe is also a difficult estimation. The Escrit table (Table 1) allowed a piecewise function based on full volume through the pipe. There was potential error involved in these calculations related to transducer accuracy, measurement of slope and Qmax. The installation of the flumes improved the accuracy of the flow measurement .

The flumes could not counteract all sampler problems. The sampler batteries caused problems, as well. They needed to be monitored and charged regularly; however, during very long storms they would sometimes have insufficient charge to sample the full storm. The 
samplers could malfunction without warning. On several occasions the sampler program froze or stopped sampling prematurely, thus missing the event.

\subsubsection{Rain Variability}

The occurrence of rain events is stochastic. As discussed in chapter 4, the Venable enhanced bioretention system requires about a half an inch of rain for both inflow and outflow. The flumes were installed mid- June, 2016, the 6 months after flume installation were extremely dry. Table 7 shows the rainfall depths for the months between June and December. The total rainfall depths for each month were taken from the Scotts Stadium rain gauge on weather underground. The 30 year average rainfall is for the city of Charlottesville from 1981-2010 from NOAA's National Climate Data Center.The total rainfall for this 5-month period is $48 \%$ lower than the 30-year average for this area. October and November are over 50\% less than the 30-year average for the month. Lack of rain of sufficient depth reduced the effectiveness of monitoring.

Table 9. 2016 Rainfall depths (weather underground) and 30 year Average (NOAA, 2011)

\begin{tabular}{|l|r|r|}
\hline \multicolumn{3}{|c|}{ Rainfall (in) } \\
\hline Month & Depth 2016 & 30-year Avg. \\
\hline July & 2.98 & 5.32 \\
\hline August & 3.49 & 4.07 \\
\hline September & 3.62 & 4.9 \\
\hline October & 1.62 & 3.74 \\
\hline November & 1.9 & 4.09 \\
\hline Total & 13.61 & 22.12 \\
\hline
\end{tabular}




\subsection{Conclusion and Future Work}

The BMP is functioning extremely well as a tool for reducing volume and sediments. Although it appeared that the BMP was not reducing total nitrogen and total phosphorous at a significant level, the problem is likely the irreducible concentrations into the system that were observed for most storms. Based on the data from the spiked storm, the BMP functions very well when there are higher concentrations to be reduced. These enhancements may be more suitable for a site with higher inlet concentrations. For the Venable enhanced site, it would be beneficial to look at more storms with spiked inlet concentrations to better understand the function of the BMP at high concentrations. It would also be important to consider the longevity of this project with the enhancements, especially if iron is oxidizing. Future work could also explore the effects of the iron exiting or leaching out of the system.

\subsection{Appendix}

\section{Appendix A: Method Validation}

Total Nitrogen- TNT Persulfate Digestion Method ( 0.5 to $25.0 \mathrm{mg} / \mathrm{L} \mathrm{N})$

1. Add persulfate reagent powder pillow to each test tube being used

2. Add $2 \mathrm{ml}$ of sample to each test tube

a. 1 test tube must contain Deionized water

3. Shake for at least 30 seconds and put in the digester for 30 minutes at $105 \mathrm{C}$

a. Using the Hach COD reactor model 45600

4. After digestion let cool for 15 minutes

5. Add Reagent A to DI water test tube, shake and start timer, wait 3 minutes

a. Continue for each test tube

6. Add reagent B to DI water test tube, shake and start timer, wait 2 minutes

a. Continue for each test tube

7. Take the $\mathrm{TN}$ reagent $\mathrm{C}$ vials and add $2 \mathrm{ml}$ from the first vial, turn up and down 10 times

a. Continue for each test tube

8. Wait 5 minutes, wipe the DI vial, use this sample to zero the DR3900 spectrophotometer

a. On DR3900 use program $350 \mathrm{~N}$, Total LR TNT

9. Wipe each test tube before reading the results in spectrophotometer (DR 3900)

10. After reading each test tube, re-read the DI vial to make sure it still reads 
Table 1. Known vs. tested values for Total Nitrogen Persulfate Digestion Method

\begin{tabular}{|l|l|}
\hline \multicolumn{2}{|l|}{ Total N $(\mathbf{m g} / \mathbf{L})$} \\
\hline Known & Measured \\
\hline 0 & 0 \\
\hline 0.5 & 0.5 \\
\hline 1 & 0.9 \\
\hline 1.5 & 1.7 \\
\hline 2 & 2.1 \\
\hline 2.5 & 2.2 \\
\hline
\end{tabular}

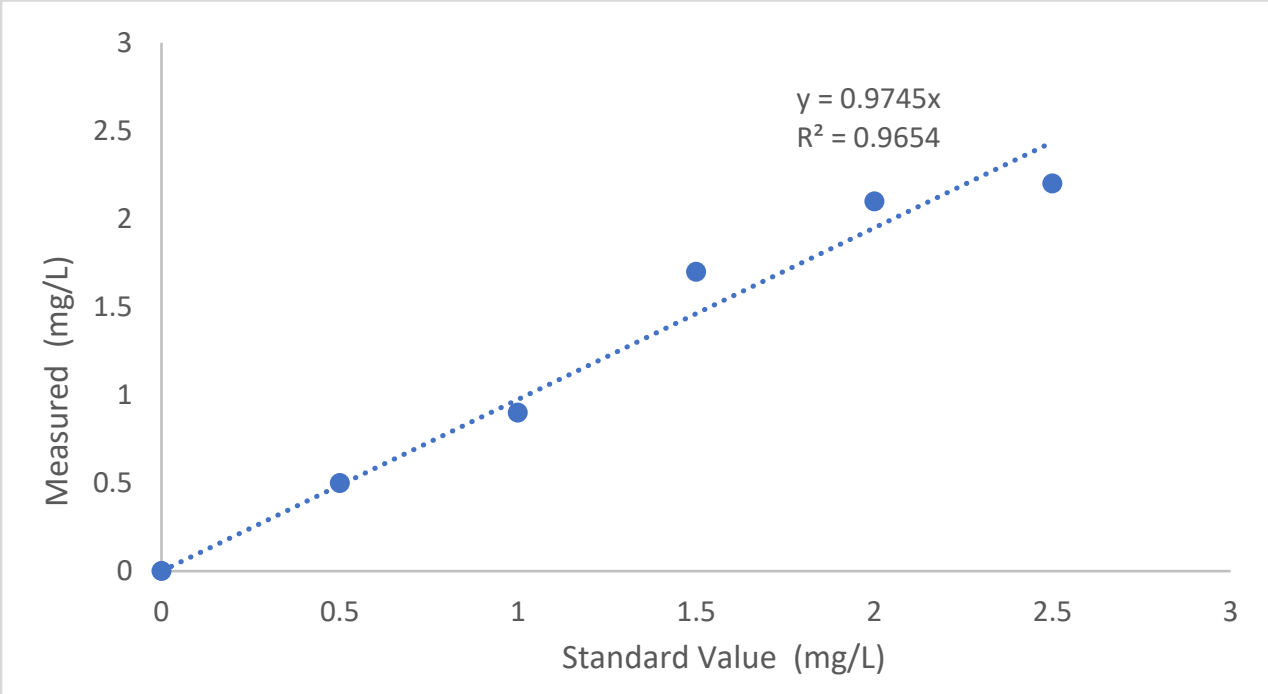

Figure 19. The calibration curve for the Total Nitrogen Persulfate Digestion Method

Using a $10 \mathrm{mg} / \mathrm{L}$ Nitrogen solution, I tested 9 different nitrogen concentrations.

- $\quad 0 \mathrm{mg} / \mathrm{L} \rightarrow 0 \mathrm{~mL}$ of Nitrogen solution \& $2 \mathrm{~mL}$ of deionized water

- $.5 \mathrm{mg} / \mathrm{L} \rightarrow .1 \mathrm{~mL}$ of Nitrogen solution $\& 1.9 \mathrm{~mL}$ of deionized water

- $\quad 1 \mathrm{mg} / \mathrm{L} \rightarrow .2 \mathrm{~mL}$ of Nitrogen solution \& $1.8 \mathrm{~mL}$ of deionized water

- $1.5 \mathrm{mg} / \mathrm{L} \rightarrow .3 \mathrm{~mL}$ of Nitrogen solution \& $1.7 \mathrm{~mL}$ of deionized water

- $\quad 2 \mathrm{mg} / \mathrm{L} \rightarrow .4 \mathrm{~mL}$ of Nitrogen solution \& $1.6 \mathrm{~mL}$ of deionized water

- $\quad 2.5 \mathrm{mg} / \mathrm{L} \rightarrow .5 \mathrm{~mL}$ of Nitrogen solution \& $1.5 \mathrm{~mL}$ of deionized water

The total nitrogen reading range is from 0 to $25 \mathrm{mg} / \mathrm{L}$. Storm water samples from Venable are within a range of 0 to $2.5 \mathrm{mg} / \mathrm{L}$. 5 total nitrogen samples made from standard stock solution within the storm water range were run for method validation. The method validation produced a linear curve shown in figure 1. The samples were run through a DR3900 spectrophotometer using the $350 \mathrm{TN}$ program. The spectrophotometer reads total nitrogen to an accuracy of one decimal place, a tenth of a $\mathrm{mg} / \mathrm{L}$. The spectrophotometer's relative imprecision adds an inaccuracy to the total nitrogen method. Given the imprecise readings of the DR3900 the resulting linear curve shown in figure 1 is quite accurate with an $\mathrm{R}$ squared value of .9654 . 
Nitrate- TNT $835\left(.2\right.$ to $\left.13.5 \mathrm{mg} / \mathrm{L} \mathrm{NO}_{3}-\mathrm{N}\right)$

1. Add $1 \mathrm{~mL}$ of sample to each of the vials

2. Add $.2 \mathrm{~mL}$ of Solution A to each vial

3. Turn up and down 2-3 times

4. Wait 15 minutes

5. Wipe down vials and read in DR3900 spectrophotometer: barcode program

Table 2. known vs. measured values found for Nitrate TNT 835 method

\begin{tabular}{|l|l|}
\hline \multicolumn{2}{|l|}{ Nitrate $\mathrm{NO}_{3}-\mathbf{N}(\mathrm{mg} / \mathrm{L})$} \\
\hline Known & Measured \\
\hline 0.000 & 0 \\
\hline 0.487 & 0.511 \\
\hline 0.975 & 0.95 \\
\hline 1.462 & 1.44 \\
\hline 1.998 & 2.01 \\
\hline
\end{tabular}



Figure 20. Calibration curve for Nitrate TNT 835 test

Concentrations of nitrogen were made from a stock solution of $10 \mathrm{mg} / \mathrm{L}$ of $\mathrm{N}$. The concentrations were measured in NO3-N (mg/L).

- $\quad .5 \mathrm{mg} / \mathrm{L} \rightarrow .05 \mathrm{~mL}$ of solution \& $.95 \mathrm{~mL}$ of DI water

- $\quad 1 \mathrm{mg} / \mathrm{L} \rightarrow .1 \mathrm{~mL}$ of solution $\& .90 \mathrm{~mL}$ of DI water

- $\quad 1.5 \mathrm{mg} / \mathrm{L} \rightarrow .15 \mathrm{~mL}$ of solution \& $.85 \mathrm{~mL}$ of DI water

- $\quad 2.05 \mathrm{mg} / \mathrm{L} \rightarrow .205 \mathrm{ml}$ of solution \& $.795 \mathrm{~mL}$ of DI water

The nitrate method has a range of .2 to $13.5 \mathrm{mg} / \mathrm{L}$. The storm water range is from .2 to $2.0 \mathrm{mg} / \mathrm{L}$. 4 solutions within the storm water range were made from a stock solution of Nitrogen. These solutions were tested using the nitrate TNT 835 method. The solutions were read in the DR3900 
spectrophotometer. The DR3900 reads the nitrate concentration to an accuracy of 3 decimal places, making it much more accurate than the Total Nitrogen Persulfate Digestion method. The linear curve for the method validation is shown in figure 2 . This resulting curve is quite accurate giving a $\mathrm{R}$ squared value of .9993 .

\section{Total Phosphorous TNT 843 (.05 to $\left.1.5 \mathrm{mg} / \mathrm{L} \mathrm{PO}_{4}-\mathrm{P}\right)$}

1. Add $2 \mathrm{~mL}$ of sample to each of the vials

2. Remove the tinfoil on the Dosi-cap, turn upside down and screw cap on

3. Turn vials upside down 2-3 times

4. Heat digestor to $105 \mathrm{C}$, and place vials in for 1 hour

5. After 1 hour, let vials cool for 10 minutes

6. After cooling add $.2 \mathrm{~mL}$ of solution $\mathrm{B}$ to each vial

7. Next add Dosi-cap C (grey cap) to each vial

8. Turn upside down 2-3 times

9. Wait 10 minutes, wipe off vial, and read in DR3900 spectrophotometer: barcode program

Table 3. Known vs measured values for Total Phosphorous TNT 843 method

\begin{tabular}{|c|r|}
\hline \multicolumn{2}{|c|}{ Total P (mg/L) } \\
\hline Known & Measured \\
\hline 0.000 & 0.000 \\
\hline 0.048 & 0.042 \\
\hline 0.097 & 0.091 \\
\hline 0.146 & 0.143 \\
\hline 0.326 & 0.349 \\
\hline 0.489 & 0.499 \\
\hline
\end{tabular}

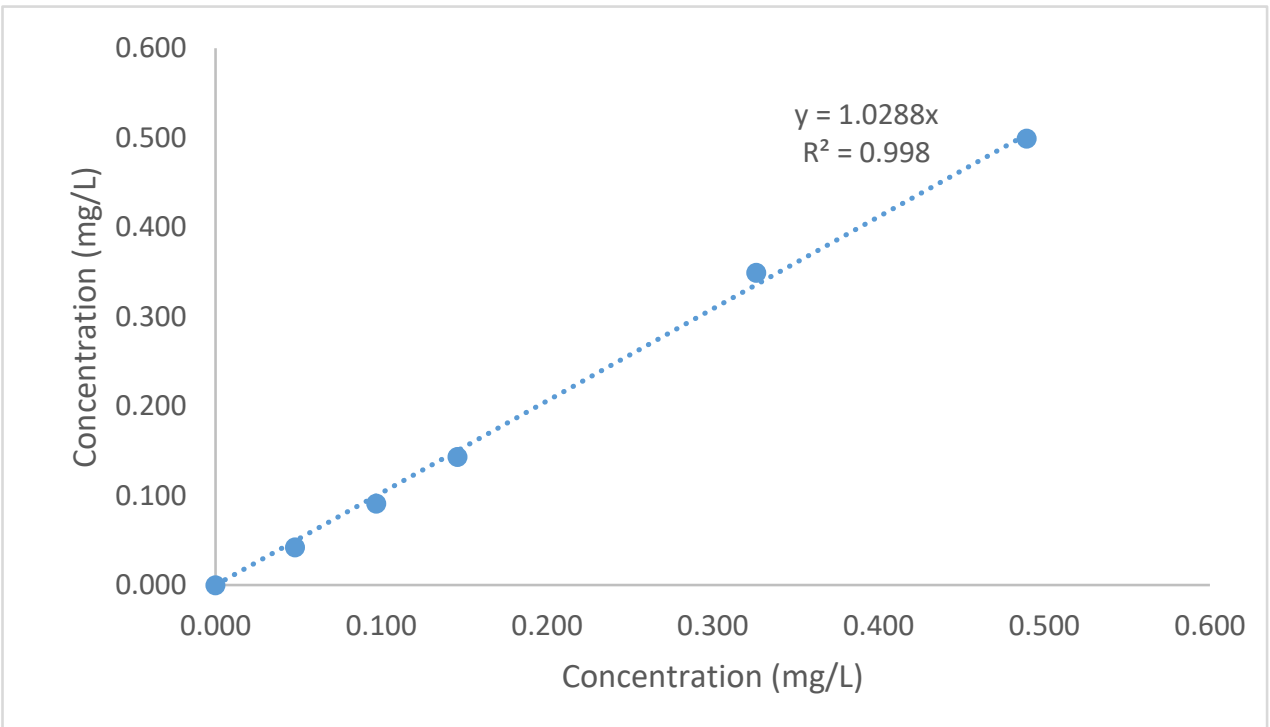

Figure 21. The calibration curve for Total Phosphorous using the TNT 843 method 
Concentrations were made from a stock solution of phosphate $3 \mathrm{mg} / \mathrm{L}$, which is equivalent to $.9787 \mathrm{mg} / \mathrm{L}$ PO4-P. Using the molecular weight of $\mathrm{P}$ as $30.973 \mu \mathrm{g} / \mathrm{L}$ and the molecular weight of PO4 as $94.93 \mu \mathrm{g} / \mathrm{L}$ :

Total PO4-P = Total PO4 * (30.973/94.93).

$30.973 / 94.93=.326$

- $\quad .048 \mathrm{mg} / \mathrm{L} \rightarrow .1 \mathrm{~mL}$ of solution $\& 1.9 \mathrm{~mL}$ of DI water

- $\quad .097 \mathrm{mg} / \mathrm{L} \rightarrow .2 \mathrm{~mL}$ of solution $\& 1.8 \mathrm{~mL}$ of DI water

- $\quad .146 \mathrm{mg} / \mathrm{L} \rightarrow .3 \mathrm{~mL}$ of solution $\& 1.7 \mathrm{~mL}$ of DI water

- $.326 \mathrm{mg} / \mathrm{L} \rightarrow .660 \mathrm{~mL}$ of solution $\& 1.340 \mathrm{~mL}$ of DI water

- $.489 \mathrm{mg} / \mathrm{L} \rightarrow 1 \mathrm{~mL}$ of solution $\& 1 \mathrm{~mL}$ of DI water

- $.653 \mathrm{mg} / \mathrm{L} \rightarrow 1.340 \mathrm{~mL}$ of solution $\& .660 \mathrm{~mL}$ of DI water

- $\quad .979 \mathrm{mg} / \mathrm{L} \rightarrow 2 \mathrm{~mL}$ of solution $\& 0 \mathrm{~mL}$ of DI water

The Total Phosphorous TNT 843 method range is from .05 to $1.5 \mathrm{mg} / \mathrm{L}$. The storm water at Venable range is much smaller, only ranging from 05 to $.5 \mathrm{mg} / \mathrm{L}$, some samples actually measuring under this range. The DR3900 measures total phosphorous samples to an accuracy of three decimal places, a thousandth of a $\mathrm{mg} / \mathrm{L}$. As shown in Figure 3, the validation curve is very accurate with an R squared value of .998. Looking at the measured vs known values of the concentrations, there is minimal error.

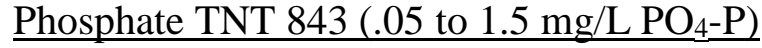

1. Add $2 \mathrm{~mL}$ of sample to each vial

2. Add .2 mL of solution $B$ to each vial

3. Read the vial with sample and solution B

4. Then put on Dosi-cap C

5. Turn upside down 2-3 times

6. Wait 10 minutes then read the vials in DR3900 spectrophotometer: barcode program

Table 4. Phosphate known vs measured values

\begin{tabular}{|l|l|}
\hline \multicolumn{2}{|l|}{$\begin{array}{l}\text { Phosphate as PO4-P } \\
(\mathbf{m g} / \mathbf{L})\end{array}$} \\
\hline Known & Measured \\
\hline 0.00 & 0.00 \\
\hline 0.048 & 0.047 \\
\hline 0.097 & 0.096 \\
\hline 0.146 & 0.151 \\
\hline 0.245 & 0.238 \\
\hline
\end{tabular}




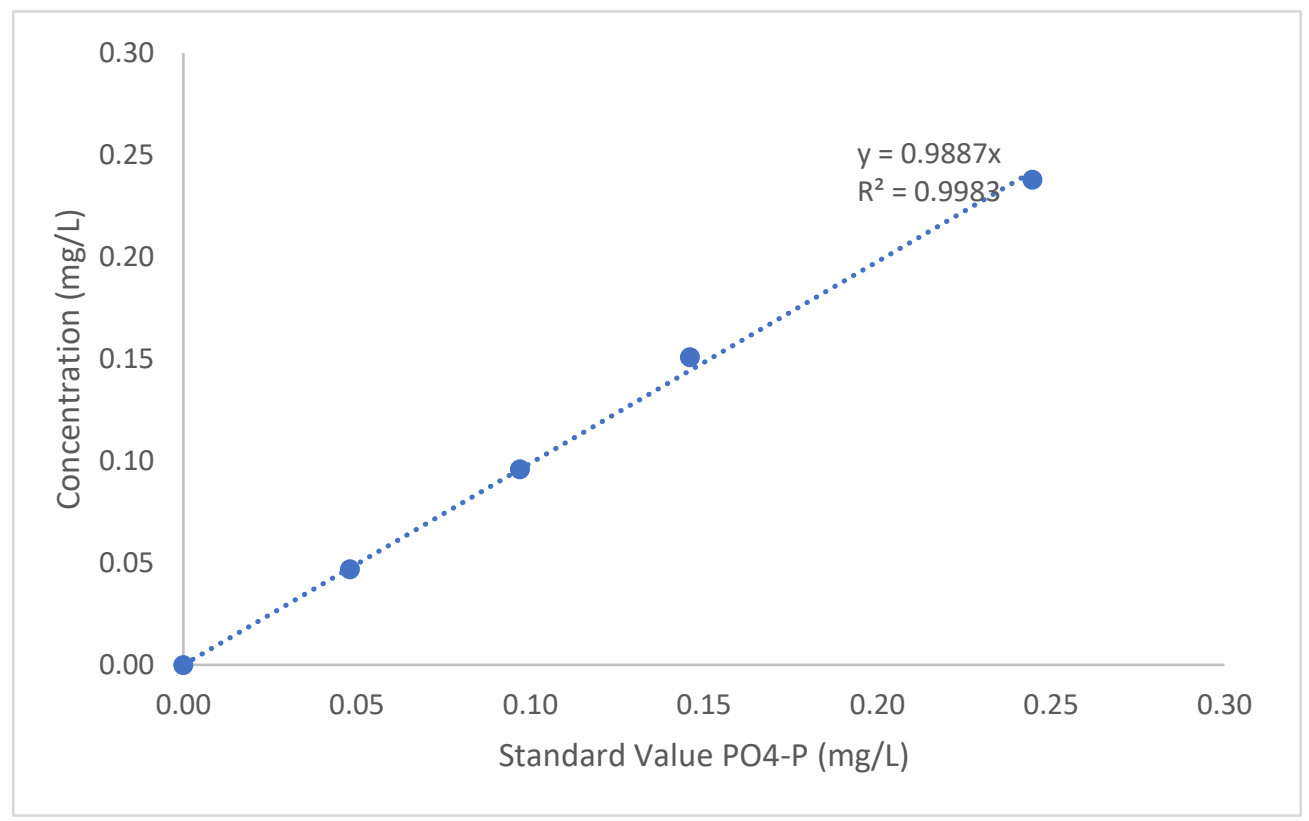

Figure 4. Calibration curve for Phosphate using method TNT 843

Table 5. Known vs Measured values of phosphate taken on 3/30/16

\begin{tabular}{|c|c|}
\hline \multicolumn{2}{|l|}{$\begin{array}{l}\text { Phosphate as PO4-P } \\
\text { (mg/L) }\end{array}$} \\
\hline Known & Measured \\
\hline 0 & 0 \\
\hline 0.05 & 0.039 \\
\hline 0.2 & 0.191 \\
\hline 0.4 & 0.39 \\
\hline 0.5 & 0.48 \\
\hline
\end{tabular}



Figure 5. The validation curve for phosphate TNT 843 method done on 3/30/26 
Concentrations were made up from a stock solution of $3.0 \mathrm{mg} / \mathrm{L}$ phosphate, which is $.9787 \mathrm{mg} / \mathrm{L}$ PO4-P. . Using the molecular weight of $\mathrm{P}$ as $30.973 \mu \mathrm{g} / \mathrm{L}$ and the molecular weight of PO4 as $94.93 \mu \mathrm{g} / \mathrm{L}$ :

$$
\text { Total PO4-P = Total PO4 * (30.973/94.93). }
$$

$30.973 / 94.93=.326$

- $\quad .048 \mathrm{mg} / \mathrm{L} \rightarrow .1 \mathrm{~mL}$ of solution $\& 1.9 \mathrm{~mL}$ of DI water

- $\quad .097 \mathrm{mg} / \mathrm{L} \rightarrow .2 \mathrm{~mL}$ of solution $\& 1.8 \mathrm{~mL}$ of DI water

- $\quad .146 \mathrm{mg} / \mathrm{L} \rightarrow .3 \mathrm{~mL}$ of solution $\& 1.7 \mathrm{~mL}$ of DI water

- $\quad .245 \mathrm{mg} / \mathrm{L} \rightarrow .5 \mathrm{~mL}$ of solution \& $1.5 \mathrm{~mL}$ of DI water

- $\quad .489 \mathrm{mg} / \mathrm{L} \rightarrow 1 \mathrm{~mL}$ of solution $\& 1 \mathrm{~mL}$ of DI water

- $\quad .734 \mathrm{mg} / \mathrm{L} \rightarrow 1.5 \mathrm{~mL}$ of solution $\& .5 \mathrm{~mL}$ of DI water

- $\quad .979 \mathrm{mg} / \mathrm{L} \rightarrow 2 \mathrm{~mL}$ of solution $\& 0 \mathrm{~mL}$ of DI water

Phosphate validations were done on two separate days, table 4 shows the phosphate validation from July, 2015 and table 5 shows the phosphate validation from March, 2016. The phosphate range is from .05 to $1.5 \mathrm{mg} / \mathrm{L}$, the same as with total phosphorous. The same Hach test kit (TNT 843 ) is used for both Total Phosphorous and Phosphate. The difference being, Phosphate samples are not heated in the digestor. The storm water range at Venable for phosphate is between .05 and $.5 \mathrm{mg} / \mathrm{L}$ with some samples being below this range. The DR3900 reads phosphate samples to 3 decimal places, a thousandth of a mg/L. Figures 4 and 5 show the validation curve for each of the phosphate validations done. Both showed very accurate measurements for phosphate with minimal error. The phosphate testing on July 2015 had an R squared value of .9983, and the testing from March 2016 had an R squared value of .9994. Both, of which, show high accuracy. 


\section{Appendix B:}

7/4/16 Storm



- 0.43 in. $(11 \mathrm{~mm})$ of rain with no outflow.

Table Appendix.6

\begin{tabular}{|c|c|c|c|}
\hline $\begin{array}{c}\text { Nitrate EMC } \\
(\mathrm{mg} / \mathrm{L})\end{array}$ & $\begin{array}{c}\text { Phosphate EMC } \\
(\mathrm{mg} / \mathrm{L})\end{array}$ & $\begin{array}{c}\text { Total N EMC } \\
(\mathrm{mg} / \mathrm{L})\end{array}$ & $\begin{array}{c}\text { Total P EMC } \\
(\mathrm{mg} / \mathrm{L})\end{array}$ \\
\hline 0.508 & 0.05 & 0.596 & 0.081 \\
\hline $\begin{array}{c}\text { Nitrate Load } \\
(\mathrm{mg})\end{array}$ & $\begin{array}{c}\text { Phosphate } \\
\text { Load }(\mathrm{mg})\end{array}$ & $\begin{array}{c}\text { Total N Load } \\
(\mathrm{mg})\end{array}$ & $\begin{array}{c}\text { Total P Load } \\
(\mathrm{mg})\end{array}$ \\
\hline 21052.177 & 2067.997 & 24702.533 & 3340.721 \\
\hline
\end{tabular}

- $100 \%$ volume reduction for this storm

- $\quad 100 \%$ volume reduction for EMCs and Loads, but this is not a far comparison to storms with outflow 


\section{Appendix C:}

The phosphate levels tested for the 5 natural storms were under detection range for all storms except the 6/17/16 storm, which had an EMC change of 0\%. Nitrate load reduction was an average of $45 \%$ over 5 storms, and the EMC reductions were negative for 3 of the 5 storms, 1 storm was under detection range.

\begin{tabular}{|r|l|l|l|l|}
\cline { 2 - 5 } \multicolumn{1}{c|}{} & Nitrate & & Phosphate & \\
\hline Event DATE & $\begin{array}{l}\text { EMC } \\
\text { Efficiency }\end{array}$ & $\begin{array}{l}\text { Load } \\
\text { Removal }\end{array}$ & $\begin{array}{l}\text { EMC } \\
\text { Efficiency }\end{array}$ & $\begin{array}{l}\text { Load } \\
\text { Removal }\end{array}$ \\
\hline $9 / 30 / 2015$ & & & & \\
\hline $11 / 9 / 2015$ & $-60 \%$ & $79 \%$ & & \\
\hline $4 / 7 / 2016$ & $-279 \%$ & $9 \%$ & & \\
\hline $6 / 17 / 2016$ & $10 \%$ & $68 \%$ & 0.00 & $64 \%$ \\
\hline $9 / 27 / 2016$ & $-119 \%$ & $49 \%$ & & \\
\hline
\end{tabular}




\subsection{References}

American Public Health Association, American Water Works Association, and Water Pollution and Control Federation, 1995, Standard Methods for the Examination of Water and Wastewater, 1995, Total Suspended Solids Dried at $103^{\circ}-105^{\circ} \mathrm{C}$, Washington, D.C., American Public Health Association, Method 2540D, p. 2-56.

American Society for Testing and Materials (ASTM), 2000, Standard test methods for determining sediment concentration in water samples: D 3977-97, vol. 11.02, Water (II), $395-400$

Ahmad, M., Upamali, A., Eun, J., Zhang, M., Bolan, N., Mohan, D., ... Sik, Y. (2014). Chemosphere Biochar as a sorbent for contaminant management in soil and water : A review. Chemosphere, 99, 19-33. http://doi.org/10.1016/j.chemosphere.2013.10.071

Akgiray, Ö. (2004). Simple Formulae for Velocity, Depth of Flow , and Slope, 21(3).

Anderson, C. R., Condron, L. M., Clough, T. J., Fiers, M., Stewart, A., Hill, R. A., \& Sherlock, R. R. (2011). Pedobiologia - International Journal of Soil Biology Biochar induced soil microbial community change : Implications for biogeochemical cycling of carbon, nitrogen and phosphorus. Pedobiologia - International Journal of Soil Biology, 54(5-6), 309-320. http://doi.org/10.1016/j.pedobi.2011.07.005

Brown, R., Hunt, W., \& Kennedy, S. (2009). Urban Waterways: Designing Bioretention with an Internal Water Storage (IWS) Layer. North Carolina Cooperative Extension Service, 1-14. Retrieved from http://www.bae.ncsu.edu/stormwater/PublicationFiles/IWS.BRC.2009.pdf

Center for Watershed Protection. (2004). Findings from the National Stormwater Qualiy Database (NSQD): Research Progress Report. Reterieved April 13, 2017 from http://chesapeakestormwater.net/wp-content/uploads/downloads/2012/02/National-SWQuality-Database-report.pdf

Chesapeake Bay Foundation. (2017). Nitrogen \& Phosphorus. Retrieved April 11, 2017, from http://www.cbf.org/about-the-bay/issues/dead-zones/nitrogen-phosphorus

Chiu, P., \& Imhoff, P. (2016). MATS UTC Final Project Report Part1

Chiu, P., Imhoff, P, Culver, T. (2014). Simultaneous Removal of Nitrogen and Phosphorous from Stormwater by Zero-Valent Iron and Biochar in Bioretention Cells.MATS UTC Research Proposal

Copeland, C. (2012). CRS Report for Congress Clean Water Act and Pollutant Total Maximum Daily Loads (TMDLs).

Ecosystem Services, LLC. (2015, March 26). Venable Elementary Bioretention Cover. Charlottesville, Virginia.

Ecosystem Services, LLC. (2015, June 1). Venable Elementary Bioretention Section Views. Charlottesville, Virginia

Environmental Protection Agency. (2017, March 02). Program Overview: Total Maximum Daily Loads (TMDL). Retrieved April 11, 2017, from https://www.epa.gov/tmdl/program- 


\section{overview-total-maximum-daily-loads-tmdl}

Environmental Protection Agency. (2017, February 21). Impaired Waters and TMDLs: Identifying and Listing Impaired Waters. Retrieved April 11, 2017 from https://www.epa.gov/tmdl/impaired-waters-and-tmdls-identifying-and-listing-impairedwaters

Environmental Protection Agency. (2017, January 23). NPDES Permit Basics Retrieved April 8, 2017 from https://www.epa.gov/npdes/npdes-permit-basics

Environmental Protection Agency. (2016). National Summary of State Information. Retrieved April 11, 2017, from https://ofmpub.epa.gov/waters10/attains_nation_cy.control

Environmental Protection Agency. (2016, Sept 29). Chesapeake Bay TMDL Fact

Sheet. Retrieved April 11, 2017, from https://www.epa.gov/chesapeake-baytmdl/chesapeake-bay-tmdl-fact-sheet

Fu, F., Dionysiou, D. D., \& Liu, H. (2014). The use of zero-valent iron for groundwater remediation and wastewater treatment: A Review. Journal of Hazardous Materials, 194205.

Hach Ascorbic Acid Method. (2016). Phosphorus , Reactive ( Orthophosphate ) and Total, 1-8.

Hach Method 10071. (2014). TNT Persulfate Digestion Method, 381-389.

Hach Tntplus Method 10206. (2015). Hach Company TNTplus 835 / 836 Nitrate Method 10206 Spectrophotometric Measurement of Nitrate in Water and Wastewater.

Irreducible Pollutant Concentrations Discharged From Stormwater Practices. (1995). Watershed Protection Techniques, 2(2), 372.

Larm, T., \& Hallberg, M. (2008). Design methods for stormwater treatment - Site specific parameters, $1-10$.

National Oceanic and Atmostpheric Administration. (2011). Data Tools 1981-2010 Normals: Monthly Normals. retrieved April 10, 2017 from https://www.ncdc.noaa.gov/cdoweb/datatools/normals

Schueler, T.R. and Holland H.K. (2000) The practice of watershed protection; techniques for protecting our nation's streams, lakes, rivers, and estuaries. Center for Watershed Protection Publishers, Ellicott City.

Senate of Virginia. (2011, November 18). Senate Finance Committee: Chesapeak Bay TMDL Watershed Implementation Plan. Reterieved April 3, 2017 from http://sfc.virginia.gov/pdf/retreat/2011\%20Retreat/Presentation_Final\%20PDF\%20for\%20 Website/5.Chesapeake\%20Bay\%20TMDL\%20FINAL.pdf

Shin, K., \& Cha, D. K. (2008). Microbial reduction of nitrate in the presence of nanoscale zerovalent iron, 72, 257-262. http://doi.org/10.1016/j.chemosphere.2008.01.043

Strecker, B. E. W., Quigley, M. M., Member, A., Urbonas, B. R., Jones, J. E., \& Clary, J. K. 
(2001). Determining Urban Stormwater BMP Effectiveness. Water Resources Planning Management, 127(June), 144-149.

Suzuki, T., Moribe, M., Oyama, Y., \& Niinae, M. (2012). Mechanism of nitrate reduction by zero-valent iron: Equilibrium and kinetics studies. Chemical Engineering, 183, 271-277.

United States Department of Agriculture. (as of April 06, 2017). Virginia and The Chesapeake Bay. Natural Resources Conservation Service. Retrieved April 06, 2017, from https://www.nrcs.usda.gov/wps/portal/nrcs/detailfull/va/home/?cid=nrcs142p2_018880

United Stated Department of the Interior Bureau of Reclamation. (2001). Water Measurement Manual: A Water Resources Technical Publication. Retrieved April 9, 2017 from https://www.usbr.gov/tsc/techreferences/mands/wmm/

Uzoma, K. C. (2011). Influence of biochar application on sandy soil hydraulic properties and nutrient retention.

Virginia Department of Environmental Quality \& Virginia Water Resources Research Center. (2016). Virginia Runoff Reduction Method, VRRM New Development Spreadsheet. Retrieve April 22, 2017 from http://www.vwrrc.vt.edu/swc/Virginia\%20Runoff\%20Reduction\%20Method.html

Virginia Department of Environmental Quality \& Virginia Water Resources Research Center. (2014, April 23). Virginia Stormwater BMP Clearinghouse . Retrieved April 5, 2017 from http://www.vwrrc.vt.edu/swc/StandardsSpecs.html

Virginia Department of Environmental Quality (2014). Final 2014 305(b)/303(d) Water Quality Assessment Integrated Report: Executive Summary. Retrieved April 6, 2017 from http://www.deq.virginia.gov/Portals/0/DEQ/Water/WaterQualityAssessments/IntegratedRe port/2014/ir14_Executive_Summary.pdf

Virginia Department of Environmental Quality. (2011, March 1). Virginia BMP Clearinghouse: Virginia DCR Stormwater Design Specifications No.9. Bioretention, Version 1.8

Viginia Department of Environmental Quality.(2008, April 18). Technical Memorandum: The Runoff Reduction Method. Center for Watershed Protection \& Chesapeake Stormwater Network.

Washington Stormwater Center. (2017). 4.4.2.2 Bioretention Components. Retrieved April 09, 2017, from http://www.wastormwatercenter.org/4422-bioretention-components

Simpson, T. \& Weammert, S. (2009). Developing Best Management Practice Definitions and Effectiveness Estimates for Nitrogen, Phosphorous and Sediment in the Chesapeake Bay Watershed Final Report December 2009, (December).

Yao, Y., Gao, B., Zhang, M., Inyang, M., \& Zimmerman, A. R. (2012). Chemosphere Effect of biochar amendment on sorption and leaching of nitrate, ammonium, and phosphate in a sandy soil. Chemosphere, 89(11), 1467-1471.

http://doi.org/10.1016/j.chemosphere.2012.06.002 
